\title{
KONSEP AL-ASHÎL DAN AL-DAKHÎL DALAM TAFSIR ALQURAN
}

\author{
Muhammad Ulinnuha \\ Institut IImu Alquran (IIQ) Jakarta \\ Jl. Ir.Juanda No.70 Ciputat, Jakarta \\ E-mail:maznuha@gmail.com
}

\begin{abstract}
The Concept of al-Ashîl and al-Dakhîl in the Quranic Exegesis. This study examined the concept of al-ashîl and al-dakhîl in the Quranic exegesis. These two issues were important to discuss because in the books of exegesis there were many data and information that were irrelevant to the content of verses and sublime messages of the Quran. Even authoritative exegesis books were also not sterile from the infiltration of interpretation, either in the form of historical data, ra'y (the result of ijtihad) or inner cues. Based on this, this study aimed to explain the concept of ashâlat al-mashdar (source authenticity) so that al-dakhîl fî al-tafsîr (infiltration of interpretation) could be known, criticized and evaluated. Criticism of the infiltration of quranic interpretation was necessary so that the exegesis books—as a work in direct contact with the main source of Islam-were completely cleansed from the reality of al-dakhîl.
\end{abstract}

Keywords: al-dakhîl; infiltration of exegesis; al-ashîl; exegesis criticism.

\begin{abstract}
Abstrak: Konsep al-Ashîl dan al-Dakhîl dalam Tafsir Alquran. Penelitian ini menguji konsep al-ashîl dan al-dakhîl dalam tafsir Alquran. Kedua isu ini penting untuk didiskusikan karena dalam kitab tafsir banyak data dan informasi yang tidak relevan dengan isi ayat dan pesan luhur Alquran. Bahkan kitab-kitab tafsir yang otoritatif juga tidak steril dari infiltrasi penafsiran, baik dalam bentuk data historis, ra'y (hasil ijtihad) atau isyarat batin. Berdasarkan hal tersebut, penelitian ini bertujuan untuk menjelaskan konsep ashâlat al-mashdar (keaslian sumber) sehingga al-dakhîl fî al-tafsîr (infiltrasi interpretasi) dapat diketahui, dikritik dan dievaluasi. Kritik terhadap infiltrasi interpretasi Alquran diperlukan agar kitab-kitab tafsir—sebagai karya yang berhubungan langsung dengan sumber utama Islam—benar-benar dibersihkan dari kenyataan al-dakhîl.
\end{abstract}

Kata kunci: al-dakhîl; infiltrasi penafsiran; al-ashîl; kritik tafsir.

\section{Pendahuluan}

Tafsir adalah produk pemikiran manusia. ${ }^{1}$ Sepanjang tafsir merupakan produk manusia, maka hal itu tidak akan lepas dari kekurangan atau bahkan penyelewengan. Di antara bentuk penyelewengan (inhirâf) itu adalah dimasukkannya data-data yang tidak valid ke dalam pembahasan tafsir Alquran yang kemudian disebut dengan istilah al-dakhîl (infiltrasi). Menurut Abdul Wahhab Fâyed, ${ }^{2}$ praktek infiltrasi penafsiran itu tidak

${ }^{1}$ Tafsir disebut dengan hasil pemikiran karena semua produk penafsiran (baik yang terkategori tafsir bi al-ma'tsur, bi al-ra'yi maupun bi al-isyârah) tidak ada yang steril dari kontribusi akal/ijtihad penulisnya.

${ }^{2}$ Baca selengkapnya pada Abdul Wahhab Fayed, al-Dakhîl fî Tafsîr al-Qur'ân al-Karîm (Kairo: Matba'ah al-Hadharah al'Arabiyah, 1978), Juz I, h. 102-108. saja terjadi pada era kontemporer, tapi secara genealogis sudah terjadi sejak masa-masa klasik seiring dengan penyebaran Islam ke berbagai penjuru dunia.

Hal itu dapat dijumpai dalam beberapa karya tafsir klasik maupun modern, dengan adanya sistem, orientasi dan metode penafsiran yang tidak sesuai (incompatible). Kecenderungankecenderungan itu semakin tampak seiring dengan munculnya pola-pola baru dalam menafsirkan Alquran, terutama dengan semakin menguatnya gairah untuk memberikan makna yang lebih memuaskan keinginan mufasir dalam memahami Alquran, dengan berusaha mengelaborasi metodologi tafsir yang tidak seluruhnya steril dari semangat kepentingan. 
Pada era sahabat sendiri ${ }^{3}$ sudah terjadi penyelewengan tafsir. Contohnya adalah penafsiran Qudâmah ibn Mazh'ûn al-Khâthi' (w.36 H) terhadap Q.S. al-Mâ'idah [5]:93. Qudâmah menganggap bahwa khamr boleh dikonsumsi dengan dua syarat; pelakunya memiliki keimanan dan rajin beramal saleh, bertakwa dan berbuat kebajikan secara terus menerus. Belakangan terungkap bahwa penafsiran Qudâmah atas Q.S. al-Mâ'idah [5]:93 itu dilakukan dalam rangka menjustifikasi kegiatan pesta khamr yang kerap ia lakukan ketika menjadi Amîr (gubernur) di daerah Bahrayn pada era Khalifah 'Umar ibn al-Khattab. ${ }^{4}$ Benih-benih penyelewengan penafsiran seperti ini terus berlangsung pada masa tabiin, tabi' tabiin, generasi pertengahan hingga sekarang.

Fenomena di atas mendorong para ahli Alquran untuk melakukan kritik evaluatif dengan membuat metode dan prosedur kritiknya. Diantaranya adalah metode kritik terhadap hadis maudlu', kritik isra'iliyat dan kritik al-dakhîl dalam karya-karya tafsir. Tulisan ini secara spesifik berusaha untuk menjelaskan hal ihwal metode kritik al-dakhîl (infiltrasi) penafsiran Alquran.

\section{Definisi Otentisitas dan Infiltrasi Penafsiran}

Dalam menafsirkan Alquran, mufasir sering terpengaruh oleh latar belakang keilmuan dan ideologinya. Mufasir yang ahli bahasa cenderung menafsirkan Alquran secara lingustik, seorang sufi cenderung menafsirkan secara intuitif dan begitu seterusnya. ${ }^{5}$ Tafsir yang diwarnai secara kuat oleh background keilmuan dan ideologi mufasirnya disinyalir tidak lagi objektif. Oleh karenanya, ulama meletakkan dasar dan metodologi penafsiran secara ketat agar mufasir tidak terjebak pada romantisme pra-konsepsi dan ideologi yang dimilikinya di satu sisi, dan supaya

3 Nama lengkapnya adalah Ibrahim 'Abd al-Rahman Muhammad Khalîfah. Guru Besar dan mantan Ketua Prodi Tafsir, Fakultas Ushuluddin, Universitas Al-Azhar Kairo, Mesir.

4 Ibrahim 'Abd al-Rahman Muhammad Khalifah, (selanjutnya disebut Ibrahim Khalifah), al-Dakhîl fî al-Tafsîr, (Kairo: Universitas Al-Azhar, 1996), h. 11 dan 118-122.

5 Model-model penafsiran yang terpengaruh dengan latarbelakang keilmuan mendapat kritik tajam dari Amin alKhuli. Sebab penafsiran semacam itu tidak mampu mengetengahkan Al-Qur'an secara objektif dan universal. Karena itu ia menawarkan konsep kritik penafsiran dengan pendekatan literary criticism. Lihat Amin al-Khuli, al-Tafsîr: Ma'âlim Hayâtih, Manhajuhu al-Yawm, (Kairo: Dâr al-Ma'rifah, 1962), h. 40-46. tafsir yang dihasilkan mencapai titik objektifnya di sisi yang lain.

Objektifitas dalam penafsiran tidak mungkin dapat dilakukan seratus persen. Maka benar pernyataan Hasan Hanafi (I. 1935 M) bahwa setiap penafsiran, baik yang menggunakan pendekatan rasional (bi al-'aql) maupun riwayat (bi al-naql), selalu berangkat dari kepentingan, tidak ada penafsiran yang sepenuhnya objektif, absolut dan universal. ${ }^{6}$ Kendatipun demikian, subjektifitas penafsiran bukan berarti tidak dapat diminimalisir dan dikendalikan. Abou el-Fadl (I. 1963 M) misalnya, menawarkan hermeneutika negosiasi’ untuk mengendalikan subjektifitas dan kepentingan mufasir tersebut. Itu artinya, penafsiran dapat didekatkan kepada titik objektifitasnya dengan menggunakan metode dan pendekatan ilmiah.

Sementara Fayed (1936-1999 M) juga menawarkan pendekatan ashâlat al-mashdar (otentisitas sumber) untuk mengetahui dan mengukur tingkat objektifitas penafsiran. Secara singkat, pendekatan ini meniscayakan verifikasi sumber data penafsiran; apakah sumbernya termasuk al-ashîlah (otentik) ataukah al-dakhîlah (terkontaminasi/terinfiltrasi dimensi lain). Orisinalitas dan otentisitas sumber penafsiran itu disebut dengan istilah al-ashîl. ${ }^{8} \mathrm{Al}$-ashîl inilah

6 Hasan Hanafi, Islam in the Modern World: Religion, Ideology and Development, (Kairo: Anglo-Egyptian Bookshop, 1995), Vol I, h. 184. Lihat juga Ilham B. Saenong, Hermeneutika Pembebasan: Metodologi Tafsir Al-Qur'an Menurut Hasan Hanafi (Jakarta: Teraju, 2002), h. 168.

7 Menurut Abou el-Fadl, dengan hermeneutika negosiasi, penafsir/pembaca tidak saja mampu mengungkap makna teks, tapi juga dapat membongkar kepentingan yang tersimpan dalam teks. Dalam konteks ini, ia menawarkan lima syarat yang harus dimiliki mufasir untuk menjaga dan mengendalikan libido subjektifitasnya yaitu; kejujuran intelektual (honesty/amânah), kesungguhan (diligence), komprehensifitas (comprehensiveness/kâffah), rasionalitas (reasonableness) dan pengendalian diri (self restrain). Lihat Khaled Abou el-Fadl, Speaking in God's Name: Islamic Law, Authority and Women (England: Oneworld, 2003), h. 99.

8 Sebelum membedah hakekat al-dakhîl, Fâyed terlebih dulu memulai penjelasannya tentang al-ashîl atau al-ashâlah (otentisitas) dalam penafsiran Al-Qur'an. Karena al-ashîl merupakan antonim dari al-dakhîl, maka persoalan al-ashâlah ini dijelaskan lebih dulu dengan harapan agar antonimnya (al-dakhîl) dapat diketahui secara baik oleh pembaca. Dalam perspektif filsafat, metode semacam ini dikenal dengan ta'rîf al-ashyâ' bi adhdadihâ (mendefinisikan sesuatu dengan cara menjelaskan antonimnya). Tim Penulis, 'Âlam al-Ghayb wa al-Shahâdah (Tehran: Markaz al-Nûn Jam‘îyah al-Ma'ârif wa al-Tsaqâfah, 2012), h. 15. Lihat juga 'Abdul Wahhab Fayed, alDakhîl fî Tafsîr al-Qur'ân al-Karîm..., Juz 1, h. 13. 
yang kemudian dijadikan sebagai parameter untuk mengukur sejauhmana kualitas penafsiran. Jika sejalan dengan teori al-ashîl, maka sebuah tafsiran dapat dikatakan sahih dan objektif. Sebaliknya, bila berlawanan, maka tafsir dapat dikategorikan sebagai al-dakhîl yang subjektif sehingga perlu dilihat, diteliti, dievaluasi dan pada tahap tertentu, jika perlu, direkonstruksi.

Dalam konteks ini, mengetahui hakekat alashâlah (otentisitas) dalam tafsir Alquran menjadi penting. Sebab dengan mengetahui hakekat al-ashâlah-antonim al-dakhîlah-maka secara otomatis akan diketahui hakekat teori kritik aldakhîl.

Secara etimologi, al-ashîl berasal dari bahasa Arab al-ashl yang berarti asal, valid, dasar, pokok dan sumber. 9 Dalam bahasa Inggris, al-ashîl sepadan dengan kata authentic yang berarti asli, orisinil, valid dan genuine. ${ }^{10}$ Dalam bahasa Arab dikatakan, shay'un ashîlun berarti sesuatu yang memiliki asal usul kuat, rajulun ashîlun adalah pemuda yang memiliki asal-usul/silsilah yang jelas, dan memiliki akal yang kuat dan sehat." Fayrûz Âbâdî (w.817 H) dalam al-Qâmûs mengatakan bahwa al-ashl adalah dasar atau pondasi, alashîl adalah orang yang memiliki asal usul jelas. ${ }^{12}$ Dengan demikian, secara bahasa al-ashîl adalah segala sesuatu yang memiliki asal usul yang pasti, jelas, otentik, orisinil dan valid.

Secara terminologi, ahli ilmu Alquran berbeda pendapat dalam mendefinisikan term al-ashîl. Namun menurut 'Abd al-Wahhâb Fâyed, secara garis besar pendapat itu dapat dikerucutkan menjadi dua definisi: pertama, tafsir yang memiliki asal-usul, dalil-dalil dan argumentasi yang jelas dari agama. Kedua, tafsir yang ruh, dan nafasnya bersandarkan kepada Alquran, sunah, pendapat para sahabat, dan tabiin. ${ }^{13}$

9 Lihat misalnya Ahmad ibn Muhammad ibn 'Ali alFayyûmî, al-Mishbâh al-Munîr fî Gharîb al-Sharh al-Kabîr (Kairo: al-Maktabah al-'Ilmiyah, 2000), h. 119.

${ }^{10}$ Lihat John M. Echols dan Hassan Shadily, Kamus Inggris Indonesia, (Jakarta: PT. Gramedia, 1975), h. 21.

"Abu al-Fadhl Muhammad ibn Makram ibn Manzhûr (selanjutnya disebut Ibn Mazhûr), Lisân al-'Arab, ditahqiq oleh 'Abdullah 'Ali al-Kabîr, dkk., (Kairo: Dâr al-Ma'ârif), Juz 13, h. 16.

${ }^{12}$ Majd al-Dîn Muhammad ibn Ya'qûb ibn Muhammad ibn Ibrahim ibn 'Umar al-Shayrâzî al-Fayrûz Âbâdî (selanjutnya disebut Fayrûz Âbâdî), al-Qâmûs al-Muhîth wa al-Qâbûs alWasîth al-Jîmi' li Mâ Dzahaba min Kalâm al-'Arab Shamâmîth, (Bayrut: Mu'assasah al-Risalah, 1407 H), Cet. II, h. 4.

${ }^{13}$ Lihat Fâyed, al-Dakhîl fî Tafsîr al-Qur'ân al-Karîm..., Juz
Jika diperhatikan, definisi Fâyed di atas terlihat hanya mencakup satu jalur tafsir saja yaitu bi al-ma'thûr dan belum mengakomodir tafsir bi al-ra'y. Oleh karenanya, definisi al-ashîl fî al-tafsîr yang jâmi' dan mâni' (komprehensif) adalah tafsir yang memiliki sumber rujukan dan dasar yang jelas serta dapat dipertanggungjawabkan, baik sumber itu berasal dari Alquran, hadis sahih, pendapat sahabat dan tabiin yang valid, atau berasal dari rasio sehat yang memenuhi kriteria dan prasyarat ijtihad. ${ }^{14}$

Adapun ad-dakhîl secara etimologi bermakna antara lain; (a) orang yang berafiliasi kepada yang bukan komunitasnya, (b) tamu, disebut dakhîl karena ia masuk ke rumah orang lain yang dikunjunginya, (c) kata serapan, karena ia berasal dari bahasa asing, dan (d) orang asing yang datang untuk tujuan eksploitasi. ${ }^{15}$ Bahkan Ibn Manzhûr (630-711 H) mengatakan bahwa al-dakhîl adalah semua unsur eksternal yang masuk ke dalam diri manusia, dan ia dapat merusak akal, mental dan fisiknya. ${ }^{16}$ Sementara bagi al-Râghib al-Ashfihânî (w.502 H/1108 M), kata al-dakhîl yang terdiri dari huruf dâl, khâ' dan lâm berpusat maknanya pada aib dan cacat internal. ${ }^{17}$ Menurut Ibrahim Khalifah, aib dan cacat itu karena beberapa faktor, antara lain: (a) keterasingan, seperti kata serapan dan tamu yang tidak diundang; (b) cacat inderawi dan cacat lainnya yang terselubung dan tidak diketahui kecuali setelah diteliti dengan seksama, seperti penyakit, usaha makar, penipuan, keraguan, ulat dalam batang pohon dan lain lain. ${ }^{18}$

Padanan kata al-dakhîl dalam bahasa Inggris adalah outsider yang berarti orang luar ${ }^{19}$ dan infiltration yang berarti peresapan, penyusupan dan perembesan. ${ }^{20}$ Berdasarkan pemaknaan ini,

1, h. 13.

14 Husayn Muhammad Ibrahim Muhammad 'Umar, alDakhîl fî Tafsîr al-Qur'ân al-Karîm (Kairo: Universitas Al-Azhar, t.th.), h. 11.

${ }^{15}$ Lihat misalnya Ibrahim Mushthafa, et.all., al-Mu'jam alWasîth, (Istanbul: Dâr al-Da‘wah, 1990), h. 275.

${ }^{16}$ Ibn Mazhûr, Lisân al-'Arab, (Bayrut: Dâr Shâdir, 1956), Jilid 11, h. 241.

17 al-Râghib al-Ashfihânî, al-Mufradât fî Gharîb al-Qur'ân (Libanon: Dâr al-Ma'rifah, t.th.), h. 166.

${ }^{18}$ Ibrahim Khalifah, al-Dakhîl fî al-Tafsîr, (Kairo: Universitas Al-Azhar, 1996), Jilid 1, h. 2.

19 John M. Echols dan Hassan Shadily, Kamus Inggris Indonesia..., h. 39.

20 Lihat John M. Echols dan Hassan Shadily, Kamus 
maka secara bahasa, virus atau bakteri penyakit dapat disebut al-dakhîl karena ia merupakan unsur eksternal yang meresap ke dalam tubuh manusia. Kata serapan juga dapat disebut al-kalimah aldakhîlah karena ia tidak berasal dari rahim atau rumpun bahasa aslinya.

Sementara secara terminologis, al-dakhîl adalah penafsiran Alquran yang tidak memiliki sumber, argumentasi dan data yang valid dari agama. ${ }^{21}$ Dengan kata lain, al-dakhîl adalah penafsiran yang tidak memiliki landasan yang valid dan ilmiah, baik dari Alquran, hadis sahih, pendapat sahabat dan tabiin, maupun dari akal sehat yang memenuhi kriteria dan prasyarat ijtihad. ${ }^{22}$

Sumber al-dakhîl dapat berasal dari dua sisi; eksternal dan internal. Secara eksternal, penafsiran semacam ini berasal dari sebagian kelompok outsider yang dengan sengaja ingin memporandakan ajaran Islam. Mereka menyerang Islam dari berbagai lini, termasuk Alquran. Bangunan peradaban yang dibangun baginda Nabi Saw melalui ajaran Alquran dirongrong sedemikian rupa dengan cara misalnya, memasukkan penafsiran-penafsiran berbau mistis dan khurafat yang tidak mempunyai sumber dan data yang jelas dari doktrin agama. Penafsiran semacam itu mereka gelindingkan ke dalam Alquran dengan maksud untuk memecah belah dan merusak teologi umat. ${ }^{23}$ Sementara secara internal, al-dakhîl berasal dari sebagian kelompok insider. Mereka mengaku bagian dari Islam, tapi sesungguhnya secara politis mereka berorientasi untuk merusak ajaran Islam dari dalam. Salah satu kelompok yang dikategorikan berbahaya adalah kelompok Bâthinîyah. Dengan alibi Alquran memiliki makna lahir dan batin, kelompok ini kemudian mencetuskan beragam penafsiran yang akhirnya ingin mendegradasi dan bahkan menafikan syariat Islam. ${ }^{24}$

Inggris Indonesia..., h. 63. Kata ilfiltration sudah diserap ke dalam bahasa Indonesia menjadi "infiltrasi" yang diartikan penyusupan dan perembesan. Lihat Tim Penulis, Kamus Bahasa Indonesia (Jakarta: Pusat Bahasa Departemen Pendidikan Nasional, 2008), h. 586.

${ }^{21}$ Lihat Fâyed, al-Dakhîl fî Tafsîr al-Qur'ân al-Karîm..., Juz $1,13$.

${ }^{22}$ Fâyed, al-Dakhîl fî Tafsîr al-Qur'ân al-Karîm..., Juz 1, 13.

${ }^{23}$ Fâyed, al-Dakhîl fî Tafsîr al-Qur'ân al-Karîm..., Juz 1, 14.

${ }^{24}$ Kelompok Bathiniyah mengatakan bahwa Al-Qur'an dan hadis memiliki makna lahir dan batin. Lihat Fâyed, al-Dakhîl fî Tafsîr al-Qur'ân al-Karîm, Juz 1, h. 14-15; dan Ibn al-Qayyim alJawzi, Talbîs Iblîs (Iskandariyah: Dâr ibn Khaldun, t.th.), h. 100.
Kelompok Bâthinîyah mengatakan bahwa Alquran dan hadis memiliki makna lahir dan batin. Makna batin merupakan inti dan esensi ajaran Islam. Karena itu, orang-orang yang berhenti pada pemahaman makna lahiriah, maka hidupnya akan berada di bawah belenggu syariat. Sementara yang berani melampauinya dan mampu menangkap makna batinnya, maka ia akan keluar dari belenggu syariat tersebut dan dapat beristirahat dari beban perintah-perintah agama.

Dari penjelasan di atas dapat ditarik beberapa kesimpulan penting. Pertama, otentisitas tafsir Alquran sangat bergantung kepada validitas data dan sumber yang digunakan mufasir. Kedua, penafsiran yang berlandaskan kepada datadata yang valid dan dapat dipertanggungjawabkan secara ilmiah dapat dikategorikan sebagai penafsiran objektif. Ketiga, sumber-sumber otentik penafsiran Alquran terdiri dari Alquran, sunah Nabi, pendapat sahabat dan tabiin, kaidah bahasa Arab dan akal sehat yang memenuhi kriteria dan prasyarat ijtihad. Keempat, penafsiranpenafsiran yang tidak bersumber dari hal-hal di atas dikategorikan sebagai al-dakhîl (tafsir infiltratif) yang patut dikaji, dievaluasi, dikritisi dan direkonstruksi.

\section{Sejarah dan Bentuk-Bentuk al-Dakhîl 1. Sejarah Munculnya al-Dakhil}

Embrio al-dakhîl sejatinya telah muncul sejak sebelum Islam lahir di jazirah Arab. Pasalnya, sebelum Islam datang di Jazirah Arab, telah ada sekelompok Ahli Kitab yang sebagian besar beragama Yahudi. Mereka berhijrah dan masuk jazirah Arab pada sekitar tahun 70 Masehi. Mereka bermukim di sebuah lembah yang dikelilingi oleh pegunungan serta terdapat banyak pohon kurma, tempat itu dinamakan Yatsrib. 25 Mereka datang berbondong-bondong ke Jazirah Arab karena ramalan para pemuka agama mereka tentang diutusnya Nabi akhir zaman sebagai penerus Musa

\footnotetext{
${ }^{25}$ Kota Yatsrib diubah oleh Nabi Saw menjadi Madinah beberapa saat setelah kedatangan beliau dikota tersebut. Nama Madinah mengisyaratkan bahwa di tempat baru itu hendak diwujudkan suatu masyarakat teratur dan berperadaban. Dengan demikian, konsep Madinah adalah pola kehidupan sosial yang sopan yang ditegakkan atas dasar kewajiban dan kesadaran umum untuk patuh kepada peraturan atau hukum. Lihat Muhammad Syafii Antonio, Muhammad SAW: The Super Manager, The Super Leader, (Jakarta: Tazkia Publishing, 2007)
} 
yang akan mengembalikan mereka kepada tanah suci sebagaimana telah dijanjikan Tuhan. Selain tinggal di Yatsrib, sebagian ada juga yang hidup berkelompok di Yaman dan Yamamah. ${ }^{26}$

Interaksi sosial yang berlangsung lama inilah yang menyebabkan pertukaran kultur dan budaya di antara kaum Yahudi dan bangsa Arab. Ketika Rasul Saw datang dengan syariat Islam dan memperluas medan dakwah hingga menjamah Yatsrib, kemudian diikuti para sahabat yang berhijrah dari Mekah menuju Madinah. Mulai dari sinilah beberapa orang Yahudi masuk Islam, diantaranya adalah Ka'b ibn Mâti' al-Humayrî alAhbâr (w. 32 H), 'Abdullah ibn Salâm (w. 43 H) dan Tamîm al-Dârî (w. 40 H/66o M). Setelah memeluk Islam, mereka menjadi salah satu rujukan para sahabat dalam menafsirkan Alquran, terutama yang berkaitan dengan kisah-kisah umat terdahulu. Abû Hurayrah (w.57 H/676 M), 'Abdullah ibn 'Abbas (w. $68 \mathrm{H} / 687 \mathrm{M}$ ) dan 'Abdullah ibn 'Amr ibn al-'Ash $($ w.63 H), adalah diantara sahabat yang kerap bertanya kepada Ahli Kitab. ${ }^{27}$

Dari keterangan singkat di atas, dapat ditarik benang merah bahwa, proses merasuknya al-dakhîl ke dalam tafsir Alquran paling tidak melalui dua jalan. Pertama, ketika Rasulullah Saw tinggal di Madinah, beliau mendakwahi Ahli Kitab dari bangsa Yahudi (bani Qaynuqâ', bani Nadhîr dan bani Qurayzhah) sehingga terjadilah pertemuan antara Nabi Saw dan sahabat dengan Ahli Kitab. Proses pertemuan dan perhelatan intelektual inilah yang menyebabkan masuknya al-dakhîl dalam tafsir. ${ }^{28}$

Kedua, masuknya sebagian orang Yahudi ke dalam Islam, seperti 'Abdullah ibn Salâm (w.43 H), Mukhayrîq ibn al-Nadhîr (w.3 H/625 M) dan Ka'b al-Ahbâr (w.32 H). Ketika segelintir orang

\footnotetext{
${ }^{26}$ Muhammad Husayn al-Dzahabi, al-Tafsîr wa al-Mufassirûn, (Kairo: Dâr al-Kutub wa al-Hadîts, 1976), Jilid I, h. 25.

${ }^{27}$ Lihat Fâyed, al-Dakhîl fî Tafsîr al-Qur'ân al-Karîm..., Juz 1, h. 14-15.

${ }^{28}$ Ketika Nabi Saw tinggal di Madinah, interaksi antara Ahli Kitab dengan umat Islam tidak dapat dihindari. Hanya saja, ketika baginda Nabi masih hidup, pergerakan al-dakhîl belum begitu massif karena dua alasan. Pertama, proses penurunan Al-Qur'an masih terus berlangsung, sehingga berbagai persoalan yang muncul tidak perlu dicarikan solusinya kepada Ahli Kitab, tapi langsung dapat diatasi oleh Rasul melalui wahyu Allah. Kedua, umat Islam pada saat itu bersikap sangat hati-hati dengan tradisi, kebudayaan dan ajaran Yahudi dan Nasrani, sebab terdapat informasi valid mengenai distorsi yang menimpa kitab suci mereka. Lihat Fâyed, al-Dakhîl fî Tafsîr alQur'ân al-Karîm..., Juz 1, h. 103.
}

Yahudi memeluk Islam dan sebagian sahabat bertanya kepada mereka mengenai isi Taurat dan Injil, terutama mengenai cerita umat terdahulu yang disebutkan secara global dalam Alquran, maka terjadilah kontak pengetahuan diantara mereka. Pada awalnya, Rasul memang melarang, bahkan marah ketika melihat 'Umar ibn al-Khattab datang dengan membawa lembaran-lembaran kitab suci yang diperoleh dari Ahli Kitab. ${ }^{29}$ Tetapi seiring perjalanan waktu, ketika Islam sudah kuat dan tersebar ke seluruh penjuru Madinah dan sekitarnya, Rasul pun mengizinkan sahabat untuk meriwayatkan cerita-cerita isra'iliyat selama tidak bertentangan dengan ajaran Islam. ${ }^{30}$

Kemudian pelansiran riwayat isra'iliyat dari Ahli Kitab ini semakin marak pada masa tabiin sehingga seorang pembaca tafsir akan sulit membedakan mana cerita yang sahih dan mana cerita yang dibuat-buat oleh ahli kitab. Dan begitu seterusnya, dari generasi ke generasi, fenomena al-dakhîl dalam tafsir Alquran-khususnya al-dakhîl bi al-ma'tsûr yang berasal dari isra'iliyat-terus berkembang seiring dengan perkembangan zaman.

Adapun terkait dengan al-dakhîl dalam tafsir bi al-ra'y, para ulama mencatat ada beberapa sebab yang turut mendorong perkembangannya. Antara lain, yang paling utama adalah pemahaman mufasir yang sangat subjektif. Subjektifitas pemahaman/penafsiran tersebut terjadi karena; pertama, tidak terpenuhinya syarat-syarat sebagai penafsir Alquran. Karena itu, ketika ia bertemu dengan ayat yang secara zahir bertentangan dengan akal, mufasir langsung mengambil kesimpulan dan menerjemahkan ayat tersebut

29 Hadis larangan melansir riwayat isra'iliyat dari Ahli Kitab selengkapnya dapat dilihat misalnya pada Imam Ahmad, Musnad Ahmad, (Bayrut: Dar Shâdir, t.th.) Juz 3, h. 387.

${ }^{30}$ Ada tiga tahapan yang dilakukan Rasul Saw dalam menyikapi al-dakhîl dari riwayat isra'iliyat ini. Pertama, pelarangan secara keras dan tegas bagi kaum muslimin untuk membaca, bertanya dan mendengarkan kabar israiliyat. Hal ini dilakukan pada awal-awal gerakan dakwah di Madinah. Kedua, pemberian izin untuk mendengar riwayat isra'iliyat dengan syarat tidak membenarkan atau mendustakan riwayat tersebut, tapi cukup mengatakan "Kami beriman kepada Allah dan apa-apa yang diturunkan kepada kami..." (Q.S. alBaqarah [2]:136). Sikap seperti ini terjadi pada pertengahan masa dakwah Nabi. Ketiga, pemberian izin untuk berdiskusi dan meriwayatkan isra'iliyat dengan syarat riwayat tersebut benar-benar valid dan sesuai ajaran Islam. Sikap ini terjadi pada akhir masa dakwah Nabi dimana umat Islam sudah sangat kuat dan disegani banyak kalangan. Lihat Fâyed, al-Dakhîl fî Tafsîr alQur'ân al-Karîm..., Juz 1, h. 110-111. 
secara literal, tanpa memandang konteks dan kemungkinan makna lain yang dikandung ayat itu. Kedua, penafsiran yang berorientasi untuk menjustifikasi pandangan golongan atau kelompok tertentu, seperti yang dilakukan sebagian sekte Mu'tazilah, Bâbiyah, Bahâ'iyah dan Ahmadiyah. ${ }^{31}$ Mereka menyelewengkan tafsir Alquran menurut hawa nafsu, dan menolak teks-teks yang bertentangan dengan akidah dan keyakinan mereka.

Dari uraian di atas dapat disimpulkan bahwa potensi al-dakhîl sudah ada sebelum Islam hadir di jaziah Arab. Kemudian benih-benihnya mulai ada pada masa Rasul dan sahabat. Lalu benih-benih itu tumbuh pada masa tabiin dan terus berkembang pada masa-masa setelahnya, terutama pada masa dinasti Umayyah $(661-750 \mathrm{M})$ dan dinasti 'Abbasiyah (750-1258 M) ketika kebudayaan, tradisi penerjemahan dan kajian-kajian ilmiah dalam berbagai disiplin ilmu ditumbuhsuburkan.

\section{Faktor Penyebab Berkembangnya al-Dakhîl}

Beberapa faktor yang melatari kemunculan dan perkembangan al-dakhîl dalam tafsir Alquran adalah:

\section{a. Faktor Politik dan Kekuasaan}

Pertentangan politik yang timbul sejak akhir kekhalifahan 'Ustman ibn 'Affan dan awal kekhalifahan 'Ali ibn Abi Thalib bisa dikatakan sebagai sebab munculnya sekte-sekte yang saling menyerang dengan cara membuat hadis-hadis dan beragam penafsiran sektarian. Syi'ah Rafidhah misalnya, ${ }^{32}$ menafsirkan ayat Tabbat Yadâ Abî Lahabin wa Tabb (Q.S. alLahab [111]:1) sebagai Abu Bakar dan 'Umar ibn al-Khattab, Maraj al-Bahrayn Yaltaqiyân (Q.S. al-Rahmân [55]:19) sebagai 'Ali dan Fathimah, al-Lu'lu' wa al-Marjân (Q.S. alRahmân [55]:19) sebagai Hasan dan Husayn, 'An al-Naba' al-'Azhîm (Q.S. al-Naba' [78]:2) sebagai Ali ibn Abu Thalib, ${ }^{33}$ dan masih banyak lagi penafsiran-penafsiran subjektif yang

${ }^{31}$ Lihat Fâyed, al-Dakhîl fî Tafsîr al-Qur'ân al-Karîm..., Juz 2, h. 193-224

${ }^{32}$ Dalam konteks ini, Imam Syafíi mengatakan, "Saya tidak melihat suatu kaum yang lebih berani berdusta kepada Rasul Saw selain kaum Rafidhah".

33 Lihat Fâyed, al-Dakhîl fî Tafsîr al-Qur'ân al-Karîm..., Juz 2, h. 145; lihat juga Ibn Taymiyah, Muqaddimah fî Ushûl al-Tafsîr..., h. 86 . mendukung mazhab mereka.

Setelah itu, datang masa-masa dinasti Umayyah dan Abbasiyah. Dinasti Abbasiyah berdiri di atas puing-puing dinasti Umaiyah. Masa itu merupakan masa transisi tampuk kekuasaan dari rezim ke rezim lain. Sebagaimana lazimnya masa transisi, maka tentu saja tidak terjadi secara seketika, tapi dilakukan dengan berbagai cara dan strategi. Salah satu strategi yang digunakan adalah dengan kampanye terselubung atas nama agama. Salah satunya adalah dengan manafsirakan ayat-ayat Alquran. Contoh penafsiran infiltratif yang dilakukan adalah tafsir atas firman Allah Swt:

"Dan (ingatlah), ketika Kami wahyukan kepadamu: "Sesungguhnya (ilmu) Tuhanmu meliputi segala manusia". Dan Kami tidak menjadikan mimpi yang telah kami perlihatkan kepadamu, melainkan sebagai ujian bagi manusia dan (begitu pula) pohon kayu yang terkutuk dalam Al-Quran. Dan Kami menakutnakuti mereka, tetapi yang demikian itu hanyalah menambah besar kedurhakaan mereka." (Q.S. al-Isrâ' [17]: 60)

Diriwayatkan dari Ya'lâ ibn Murrah bahwa yang dimaksud dengan al-shajarah almal'ûnah adalah Bani Umayyah. Mereka meriwayatkan dari 'Aisyah bahwa dia berkata kepada Marwan ibn Hakam (w. 65 H), "Saya mendengar Rasul Saw berkata kepada ayah dan kakekmu, (wahai Marwan), kalian (Bani Umayyah) adalah al-shajarah al-mal'ûnah (pohon terkutuk) yang disebutkan dalam Q.S. al-Isrâ' [17] ayat 60." 34

b. Faktor Kebencian Terhadap Islam

Golongan yang tidak senang dengan Islam sengaja membuat berbagai riwayat palsu dengan tujuan untuk mengoyak Islam secara internal. Berbagai penafsiran yang tidak memiliki dasar kuat mereka buat dan sebarkan di tengah-tengah umat. Salah satu contoh al-dakhîl melalui hadis palsu yang dibuat dalam konteks ini adalah kisah Gharânîq ${ }^{35}$

34 Husayn Muhammad Ibrahim Muhammad 'Umar, alDakhîl fî Tafsîr al-Qur'ân al-Karîm, (Kairo: Universitas Al-Azhar, t.th.), h. 39-40.

${ }^{35}$ Yang dimaksud gharânîq dalam konteks ini adalah salah satu jenis berhala yang disembah kaum kafir Quraisy. Gharânîq 
yang dikaitkan dengan asbab nuzul Q.S. alHaji [22]: 53

"Dan Kami tidak mengutus sebelum kamu seorang rasulpun dan tidak (pula) seorang nabi, melainkan apabila ia mempunyai sesuatu keinginan, setanpun memasukkan godaan-godaan terhadap keinginan itu, Allah menghilangkan apa yang dimasukkan oleh setan itu, dan Allah menguatkan ayat-ayatNya." (Q.S. al-Hajj [22]:53) $)^{36}$

Tentu riwayat gharânîq ini dianggap tidak rasional dan bertentangan dengan logika hukum 'ishmah al-nubûwah (perlindungan terhadap Nabi Saw). Karenanya tidak berlebihan jika para pakar hadis dan tafsir membantah status riwayat tersebut dan menggolongkannya ke dalam hadis palsu. Beberapa diantaranya adalah Ibn 'Athiyah (481-541 H) dan Syihabuddin alAlûsî (1217-1270 H) 37.

c. Faktor Fanatisme

Fanatisme adalah sikap yang tidak baik, sebab sikap ini dapat merusak objektifitas mufasir. Diantara contoh al-dakhîl yang disebabkan faktor fanatisme adalah penafsiran sebagian kelompok Syi'ah terhadap Q.S. al-Mâ'idah [5]:55. Mereka mengatakan bahwa ketika 'Ali ibn Abi Thalib sedang shalat tiba-tiba

berasal dari kata gharnûq atau gharnîq. la merupakan nama satu jenis burung air (sejenis burung pelikan) yang berkelamin lelaki. Kaum kafir menjadikan berhala (gharânîq) sebagai sesembahan karena ia diyakini mampu memberi pertolongan dan mampu membawa terbang doa-doa yang dipanjatkan kepada Tuhan, seperti halnya burung yang mampu terbang ke angkasa. Lihat Ibn al-Atsîr, al-Nihâyah fî Gharîb al-Hadîts wa alAtsar, (Bayrut: al-Maktabah al-'Ilmiyah, 1979), Juz 3, h. 69.

${ }_{36}$ Sebagian mufasir meriwayatkan asbabun nuzul ayat tersebut bahwa ketika Rasulullah mengalami masa-masa sulit, yakni ketika ditinggal oleh kaumnya. Nabi pun berharap kaumnya tidak diazab sebab beliau optimis suatu saat mereka akan menjadi orang-orang yang beriman. Pada saat beliau sedang duduk di salah satu tempat pertemuan kaum Quraisy, tiba-tiba Allah menurunkan surat al-Najm [53].

sesuatu yang tidak aku bacakan kepadamu (dan juga) bukan berasal dari Allah?". Nabi Saw pun bersedih dan sangat takut. Maka Allah menurunkan ayat tersebut di atas (Q.S. Al-Hajj [53]: 52). Riwayat mengenai kisah gharânîq ini dapat dilihat misalnya pada kitab tafsir Abu al-Qâsim Mahmud ibn 'Umar ibn Muhammad al-Zamakhsyari (selanjutnya ditulis al-Zamakhsyari), al-Kasysyâf 'an Haqâ'iq al-Tanzîl wa 'Uyûn alAqâwîl fî Wujûh al-Ta'wîl (selanjutnya ditulis al-Kasysyâf), (Kairo: Dâr al-Kutub, t.th.), Juz 2, h. 65.

37 Ibn 'Athiyah, al-Muharrar al-Wajîz fî Tafsîr al-Kitâb al'Azîz, (Rabat: Maktabah al-Îmân, 1998), Juz 2, h. 136. Lihat juga Syihabuddin al-Alûsî, Rûh al-Ma'ânî fî Tafsîr al-Qur'ân al-'Azhîm wa al-Sab‘ al-Matsânî, (Kairo: Dar al-Manar, 2000), Juz 17, h. 182. datang seorang pengemis, maka Ali -yang sedang dalam keadaan ruku'- memberikan cincin kepada si pengemis itu. Terkait dengan kejadian inilah, maka Q.S. al-Mâ'idah [5] ayat 55 itu diturunkan. Contoh lain adalah penafsiran kaum Syi'ah atas Q.S. Qâf [50]:24. Mereka melansir sebuah riwayat palsu yang berbunyi: "Ketika kiamat datang, Allah berfirman kepadaku (Muhammad) dan 'Ali ibn Abi Thalib: 'Masukkanlah orang-orang yang kalian cintai ke surga, dan masukkanlah orangorang yang kalian benci ke neraka'. Riwayat ini —menurut mereka-merupakan tafsiran ayat Alqiyâ fî Jahannama Kulla Kaffârin 'Anîd (Q.S. Qâf [50]:24)..$^{38}$ Hal yang sama juga dilakukan oleh pengikut Muktazilah, Khawarij Murji'ah dan sekte-sekte lainnya.

\section{d. Faktor Perbedaan Mazhab}

Perbedaan (ikhtilâf) adalah suatu kepastian, sunnatullah, dan manusia tidak mungkin untuk menghindarinya. Ikhtilâf dapat dibenarkan selama tidak menyangkut masalah akidah yang prinsip, melainkan dalam masalah furû'. Karena itu, kehadiran berbagai macam sekte kerap menjadi bumerang bagi umat Islam. Mereka tidak segan-segan menjadikan Alquran sebagai alat justifikasi terhadap ajaran sekte mereka. Salah satu contonya adalah apa yang dilakukan Ahmadiyah Qadyan. Karena meyakini bahwa Mirza Ghulam Ahmad adalah seorang nabi, maka berbagai ayat yang memungkinkan untuk dijadikan pembenar ajaran tersebut, mereka tafsirkan secara subjektif sesuai ajarannya. Ketika menafsirkan Q.S. al-Nisâ' [5]:69 misalnya, mereka mengatakan bahwa frase min al-nabîyîn wa al-shiddîqîn wa alsyuhadâ' wa al-shâlihîn adalah penjelasan (bayân) bagi frase sebelumnya; wa man yuthi'illah wa al-rasûl. Berdasarkan penjelasan semacam ini maka umat Muhammad sangat dimungkinkan untuk mencapai empat derajat sebagaimana disebutkan pada ayat tersebut, yakni; kenabian (al-nubûwah), kebenaran

${ }^{38}$ Lihat contoh-contoh al-dakhîl berupa hadis palsu pada Ibn Taymiyah, Muqaddimah fî Ushûl al-Tafsîr, h. 78; Ibn Katsir, Tafsir al-Qur'ân al-'Azhîm, (Kairo: Dâr al-Turâts, 2000), Juz 3, h. 130; dan Muhammad ibn 'Ali ibn Muhammad al-Syaukânî, alFawâ'id al-Majmû'ah fî al-Ahâdîts al-Maudhû'ah, (Bayrut: Dâr Shâdir, t.th.), h. 382 . 
(al-shiddîqîyah), persaksian (al-syahâdah) dan kebaikan (al-shalâh). Dengan demikian, semua orang yang taat kepada Allah dan Rasul-Nya dimungkinkan dapat mencapai derajat kenabian, seperti halnya Ghulam Ahmad. 39

Tafsiran sektarian yang subjektif semacam inilah yang menjadikan al-dakhîl dalam tafsir Alquran semakin tumbuh subur. Padahal ketika mufasir melihat ayat di atas secara jujur dan objektif, tanpa terbelenggu dengan doktrin kenabian Ghulam Ahmad, maka ia akan mampu mempersembahkan penafsiran yang universal dan kompatibel untuk semua anak zaman. Penafsiran-penafsiran mayoritas ulama menjelaskan bahwa ayat di atas merupakan tafsiran bagi ayat ketujuh surat alFâtihah. Artinya, jalan bagi orang-orang yang tidak tersesat dan tidak dimurkai Allah adalah ketaatan kepada Allah dan Rasul-Nya yang sudah direfleksikan dan diaplikasikan oleh para Nabi, shiddîqîn, syuhadâ' dan shâlihîn..$^{40}$

e. Faktor Ketidaktahuan

Niat baik yang tidak dilandasi pengetahuan yang cukup tidak selamanya berimplikasi kepada kebaikan. Salah satu contohnya adalah apa yang dilakukan sebagian muballigh yang dengan sengaja melansir riwayat tanpa mengetahui status dan validitas riwayat tersebut. Alih-alih membawa kebaikan, riwayat-riwayat semacam itu bisa jadi malah menimbulkan polemis yang berkepanjangan.

Menurut catatan al-Suyûthî $(849-911$ H), diantara orang-orang yang kerap membuat riwayat palsu dengan maksud baik tapi tidak dibarengi dengan ilmu yang mendalam adalah Abu 'Ishmah Nuh ibn Abu Maryam (w.173 H), Maysarah ibn 'Abdi Rabbih, Bazî' ibn Hassân dan Mukhlid ibn 'Abd al-Wâhid. ${ }^{41}$ Mereka sengaja membuat riwayat-riwayat palsu mengenai keutamaan (fadhîil) suratsurat Alquran dengan tujuan agar umat Islam gemar membaca dan mengamalkan

39 Lihat Shaykh Muhammad al-Khadhir Husayn, alQadyânîyah, (Kairo: al-Makatabah al-Salafîyah, 1932), h. 59-60. Lihat juga Fâyed, al-Dakhîl fî Tafsîr al-Qur'ân al-Karîm..., Juz 2, h. 233-234.

$4^{\circ}$ Ibn Katsir, Tafsir al-Qur'ân al-'Azhîm..., Juz 1, h. 75.

${ }^{41}$ Jalaluddin al-Suyûthî, Tadrîb al-Râwî, (Kairo: Dâr alManâr, 2000), Juz 1, h. 282-289.
Alquran. Riwayat-riwayat palsu itu kemudian dinukil oleh sebagian mufasir seperti alZamakhsyari (467-538 H). Di dalam tafsirnya, al-Zamakhsyari melansir berbagai riwayat mengenai keutamaan surat-surat Alquran seperti surat al-Nâzi'ât, al-Infithâr, al-Burûj, al-Fajr, al-Dhuhâ, al-Tîn, al-Takâtsur, alKautsar, al-Kâfirûn ${ }^{42}$ dan beberapa surat lainnya. Namun setelah diselidiki ternyata status riwayat-riwayat tersebut tidak valid dan karenanya dapat dikategorikan sebagai al-dakhîl (tafsir ilfiltratif).

\section{Klasifikasi Bentuk al-Dakhîl}

Dalam buku al-dakhîl karya Fâyed dijelaskan tujuh klasifikasi al-dakhîl (infiltrasi) penafsiran yaitu; dakhîl yang berasal dari riwayat israiliyat, hadis maudhû' dan dha'îf, infiltrasi penafsiran dari sekte Bâthiniyah, ilfiltrasi penafsiran sufistik yang mengabaikan makna eksoteris, infiltrasi penafsiran dari aspek linguistik, infiltrasi penafsiran dari sekte Bâbiyah, Bahâ'iyah dan Qadyâniyah, serta ilfiltrasi penafsiran dari sebagian pemikir kontemporer. ${ }^{43}$

Namun dalam beberapa karya ulama lain, al-dakhîl diklasifikasi menjadi tiga jalur yaitu jalur al-ma'tsûr (riwayat), jalur al-ra'y (rasio) dan jalur al-isyârah (intuisi). Masing-masing jalur kemudian dibagi lagi menjadi beberapa bagian.

Pertama, al-dakhîl jalur al-atsar (riwayat), meliputi: hadis maudhû' (palsu), hadis dha'îf (lemah), riwayat isra'iliyat yang bertentangan dengan Alquran dan sunah, pendapat sahabat dan tabiin yang tidak valid, pendapat sahabat dan tabiin yang bertentangan dengan Alquran, sunah, hukum logika dan tidak dapat dikompromikan. ${ }^{44}$

Kedua, al-dakhîl dari jalur ra'y (rasio), meliputi: tafsir yang didasari niat buruk dan skeptisme terhadap ayat-ayat Allah, tafsir eksoteris tanpa mempertimbangkan sisi kepantasan bila disematkan kepada Dzat Allah, penafsiran distorsif atas ayat-ayat dan syariat Allah dengan mengabaikan sisi literal ayat, tafsir esoteris yang tidak didukung

${ }^{42}$ al-Zamakhsyari, al-Kasysyâf, terutama ketika menafsirkan juz 'Amma. Lihat juga Fâyed, al-Dakhîl fî Tafsîr al-Qur'ân alKarîm..., Juz 2, h. 59-61.

${ }^{43}$ Lihat Fâyed, al-Dakhîl fî Tafsîr al-Qur'ân al-Karîm..., Juz 1, h. 102-108.

44 Jamâl Mushthafâ 'Abd al-Hamîd 'Abd al-Wahhâb alNajjâr, Ushûl al-Dakhîl fî Tafsîr Âyi al-Tanzîl, (Kairo: Universitas Al-Azhar, 2009), h. 27. 
argumentasi yang kuat, penafsiran yang tidak berbasis pada prinsip dan kaidah tafsir yang baku, penafsiran saintifik yang terlalu jauh dari konteks linguistik, sosiologis dan psikologis ayat. ${ }^{45}$

Ketiga, al-dakhîl dari jalur al-isyârah (intuisi), meliputi antara lain: tafsir esoteris yang dilakukan oleh sekte Bâthiniyah, tafsir sebagian kaum sufi yang tidak mengindahkan makna eksoteris ayat. Secara lebih detail, klasifikasi al-dakhîl di atas dapat dilihat pada tabel berikut:

Tabel 1 : Klasifikasi Al-Dakhîl

\begin{tabular}{|c|c|c|c|}
\hline No. & $\begin{array}{l}\text { Klasifikasi } \\
\text { al-Dakhîl }\end{array}$ & Sumber & Bentuk/Macam \\
\hline 1. & bi al-Ma'tsûr & $\begin{array}{l}\text { Riwayat } \\
\text { (sunah, } \\
\text { pendapat } \\
\text { sahabat dan } \\
\text { tabiin serta } \\
\text { isra'iliyat) }\end{array}$ & $\begin{array}{l}\text { 1. Isra'iliyat; } \\
\text { 2. Hadis maudhû' (palsu); } \\
\text { 3. Hadis dha'îf (lemah); } \\
\text { 4. Pendapat sahabat dan } \\
\text { tabiin yang tidak valid; } \\
\text { 5. Pendapat sahabat } \\
\text { dan tabiin yang } \\
\text { bertentangan dengan } \\
\text { Alquran, sunah, hukum } \\
\text { logika dan tidak dapat } \\
\text { dikompromikan. }\end{array}$ \\
\hline 2. & bi al-Ra'y & Rasio/ljtihad & $\begin{array}{l}\text { 1. Tafsir yang didasari niat } \\
\text { buruk dan skeptisme } \\
\text { terhadap ayat-ayat } \\
\text { Allah; } \\
\text { 2. Tafsir eksoteris } \\
\text { (tektualis) tanpa } \\
\text { mempertimbangkan } \\
\text { sisi kepantasannya bila } \\
\text { disematkan kepada } \\
\text { Dzat Allah; } \\
\text { 3. Penafsiran distorsif } \\
\text { atas ayat-ayat dan } \\
\text { syari'at agama; } \\
\text { 4. Penafsiran yang tidak } \\
\text { berbasis pada prinsip } \\
\text { dan kaidah tafsir yang } \\
\text { disepakati mayoritas } \\
\text { ahli tafsir; } \\
\text { 5. Penafsiran saintifik } \\
\text { yang terlalu jauh dari } \\
\text { konteks linguistik, } \\
\text { sosiologis dan } \\
\text { psikologis ayat. }\end{array}$ \\
\hline 3. & bi al-Isyârah & Hati/Intuisi & $\begin{array}{l}\text { 1. Tafsir esoteris yang } \\
\text { dilakukan oleh sekte } \\
\text { Bâthiniyah, Bahâ'iyah } \\
\text { dan Qadyâniyah; } \\
\text { 2. Tafsir sebagian kaum } \\
\text { sufi yang menafikan } \\
\text { makna eksoteris ayat } \\
\text { dan tidak memiliki } \\
\text { argumentasi yang kuat. }\end{array}$ \\
\hline
\end{tabular}

Sumber: Diolah dari berbagai sumber

\section{Sumber Otentik Tafsir sebagai Parameter Kritik ad-Dakhil}

Secara umum, sumber otentik penafsiran Alquran terdiri dari; (1) Alquran, (2) sunah yang sahih, (3) pendapat sahabat dan tabiin yang valid dan dapat dipertanggungjawabkan, (4) kaidah bahasa Arab yang disepakati mayoritas ahli bahasa, (5) ijtihâd (rasio) yang berbasis pada data, kaidah, teori dan argumentasi yang dapat dipertanggungjawabkan secara ilmiah. ${ }^{46}$

Lima sumber penafsiran Alquran inilah yang menjadi basis sekaligus parameter utama dalam kritik ad-dakhîl. Oleh karena itu, bila ada penafsiran-penafsiran yang kemudian tidak berbasis kepada lima sumber di atas, dapat dikategorikan sebagai al-dakhîl yang harus dikritisi, dianalisis dan dievaluasi validitasnya.

Karena sumber-sumber otentik tersebut juga berperan sebagai parameter kritik, maka dalam sub bahasan ini, akan diuraikan satu persatu bagaimana cara kerja masing-masing komponen tersebut.

\section{Alquran}

Alquran dijadikan sebagai sumber penafsiran pertama dan utama karena ia memiliki otoritas tertinggi untuk menjelaskan dirinya sendiri. Fungsi Alquran sebagai penjelas bagi dirinya sendiri terlihat dari beberapa ayat misalnya, Q.S. alQiyâmah [75]:16-19, Q.S. al-Hadîd [57]:17, Q.S. Âli 'Imrân [3]:138, Q.S. al-Baqarah [2]:99 \& 219, Q.S. al-Mâ'idah [5]:15 dan Q.S. al- $\underline{\text { Hijr }}$ [15]:1.47 Ayatayat tersebut mempertegas bahwa salah satu fungsi Alquran adalah menjelaskan dirinya sendiri. Karena itu, tidak berlebihan jika Ibn Taymiyah pernah mengatakan bahwa metode tafsir terbaik adalah menafsirkan Alquran dengan Alquran. ${ }^{48}$

Pertanyaannya kemudian, bagaimana metode Alquran menjelaskan/menafsirkan dirinya sendiri. Diantara caranya, yaitu: (1) tafshîl al-mûjaz ${ }^{49}$

${ }^{46}$ Fayed, al-Dakhîl fî Tafsîr al-Qur'ân al-Karîm..., Juz 1, h. 15. Lihat juga Muhammad Husayn al-Dzahabî, al-Ittijâhât alMunharifah..., h. 4-5.

${ }^{47}$ Fâyed, al-Dakhîl..., Juz 1, h. 17-18.

${ }^{48}$ Lihat Ibn Taymiyah, Muqaddimah fîUshûl al-Tafsîr..., h. 93.

${ }^{49}$ Contohnyaadalah cerita tentang NabiAdam. Kadangkala ia diceritakan secara ringkas seperti yang terlihat pada Q.S. alKahfi [18] dan Q.S.al-Isrâ' [17], terkadang diceritakan secara terperinci dan detail seperti pada Q.S. al-Baqarah [2] dan Q.S. al-A'râf [7], dan ada juga yang diceritakan tidak terlalu ringkas juga tidak terlalu detail seperti yang terlihat pada Q.S. Thâhâ [20], Q.S. Shâd [38] dan Q.S. al-Hijr [15]. Kisah nabi Adam yang 
(merinci yang ringkas/global), (2) bayân almujmal $^{50}$ (menjelaskan yang belum jelas/mujmal), (3) takhshîsh al-'âm ${ }^{51}$ (mengkhususkan yang umum), (4) taqyîd al-muthlaq ${ }^{52}$ (membatasi yang mutlak/tidak terbatas), (5) penjelasan dengan cara naskh ${ }^{53}$ (penghapusan/penggantian), (6) al-taufîq

mendetail tentu dimaksudkan untuk menjelaskan dan merinci cerita yang ringkas. Lihat Fâyed, al-Dakhîl..., Juz 1, h. 18-19. Lihat juga al-Zarkasyri, al-Burhân fî 'Ulûm al-Qur'ân..., Juz 2, h. 211.

${ }^{50}$ Mujmal adalah kalimat atau ayat yang belum jelas maknanya. Adapun mubayyan adalah kalimat yang sudah jelas maknanya. Ketidakjelasan makna itu disebabkan beberapa hal antara lain; satu lafaz memiliki kemungkinan lebih dari satu makna (musytarak), perbedaan terhadap lafaz yang terbuang (hadzf), perbedaan tampat kembali kata ganti (dhamîr), perbedaan kemungkinan antara kata sambung ('athaf) dan permulaan kalimat (isti'nâf ), kata-kata asing (gharîb) dan perbedaan taqdîm dan ta'khîr. Sementara penjelasan (bayân) terhadap ayat-ayat yang belum jelas (mujmal) adakalanya dilakukan secara langsung dalam satu rangkaian ayat (muttashil), ada juga yang terpisah (munfashil). Contoh penjelasan langsung dalam satu ayat seperti yang tergambar pada Q.S. al-Baqarah [2]:187. Pada ayat ini, yang dimaksud al-khayth al-abyadh dan al-khayth al-aswad adalah al-fajr. Sementara model kedua seperti Q.S. al-Baqarah [2]:37 yang dijelaskan secara terpisah pada Q.S. al-A'râf [7]:23. Lihat Fâyed, al-Dakhîl..., Juz 1, h. 20-21.

51 'Âm adalah kata yang memberi pengertian umum, meliputi segala sesuatu yang terkandung dalam kata itu tanpa terbatas. Sementara khâsh adalah kata khusus yang diperuntukkan untuk makna-makna tertentu saja. Dalam konteks Al-Qur'an, para ulama ada yang berpendapat, hampir tidak ada kata yang umum kecuali ada kata yang mengkhususkannya. Yang mengkhusukan kata umum itu adakalanya muttashil (tersambung/langsung), adakalanya munfashil (terpisah). Yang muttashil berupa istithnâ' (pengecuali) seperti Q.S. al-Syu'arâ' [26]:224-227, al-washf (sifat) seperti Q.S. al-Nisâ' [4]:23, al-sharth (syarat) seperti Q.S. alBaqarah [2]:180, al-ghâyah (tujuan/batas) seperti Q.S.al-Baqarah [2]:187, badl al-ba'dh min al-kull (pengganti) seperti Q.S. Fâthir [35]:10. Sementara yang munfashil seperti Q.S. al-Nisâ' [4]:3 ditakhshish oleh Q.S. al-Nisâ' [4]:23-24. Lihat Fâyed, al-Dakhîl..., Juz 1, h. 22-23. Lihat pula Muhammad Su'âd Jalâl, al-Bayân wa al-Naskh fîUshûl al-Fiqh, (Kairo: Maktabah al-Nahdhah, t.th.), h. 20.

${ }_{52}$ Muthlaq adalah kata yang terlepas, tidak terikat. Artinya kata yang memberi petunjuk kepada hakikat sesuatu tanpa ikatan/batasan apa-apa. Contonya adalah kata raqabah (budak) pada Q.S. al-Mujâdalah [58]: 3. Kata itu tidak dibatasi dengan kata apapun (muthlaq) sehingga budak yang dimaksud pada ayat ini adalah semua jenis budak. Sementara muqayyad adalah kata yang menunjukkan hakikat sesuatu yang terikat dengan sesuatu yang lain. Contonya, kata raqabah mu'minah (budak mukmin) pada Q.S. al-Nisâ' [4]: 92. Kata raqabah di sini dibatasi dengan kata mu'minah, sehingga ia tidak lagi muthlaq tapi sudah muqayyad (terbatas), yakni hanya budak-budak yang mukmin saja. Menurut al-Zarkasyî, ketika ditemukan suatu dalil yang mengikat (men-taqyid) kata yang muthlaq, maka yang muthlaq itu harus ditafsirkan denganya. Dan jika tidak ditemukan dalil, maka yang muthlaq tetap pada kemutlakanya dan yang muqayyad tetap pada maknanya. Lihat al-Zarkasyî, al-Burhân fî ‘Ulûm al-Qur'ân, Juz 2, h. 15; al-Suyuthî, al-Itqân fî 'Ulûm al-Qur'ân, (Kairo: Dâr al-Manâr, 1999), Juz 2, h. 31; dan Fâyed, al-Dakhil fî Tafsîr al-Qur'ân al-Karîm..., Juz 1, h. 23.

53 Naskh adalah menghapus atau mengganti hukum syar'i dengan dalil hukum syar'i lain yang datang kemudian. bayna mâ yûhim al-ta'ârudh ${ }^{54}$ (mengkompromikan ayat-ayat yang seakan-akan berlawanan), (7) melalui qirâ'ât ${ }^{55}$ (bacaan) Alquran. ${ }^{56}$ Dengan menggunakan tujuh model rumusan inilah, mufasir dapat menjelaskan/menafsirkan Alquran dengan Alquran.

\section{Sunah Nabi Saw 57}

Sumber kedua penafsiran Alquran adalah sunah Nabi Saw. Beberapa ayat yang mendasari hal ini adalah Q.S. al-Nahl [16]:44 \& 64, Q.S. al-Hasyr [59]:7. Sementara diantara hadis Nabi Saw yang melandasinya adalah: "Hendaklah kalian berpegang teguh pada sunahku dan sunah para khulafa' rasyidin yang mendapat petunjuk sesudahku. Gigit (pegang erat) sunah tersebut dengan gigi geraham" (HR. Tirmidzi). ${ }^{8}$ Dalam hadis lain juga disebutkan: "Sesungguhnya kutinggalkan pada kamu sekalian dua perkara yang kalian tidak akan sesat apabila kalian berpegang teguh kepada keduanya, yaitu: Kitab Allah dan sunah Nabi-Nya," (HR. Malik). ${ }^{59}$ Di samping itu, ada juga beberapa

Menurut para ulama, naskh merupakan penjelasan terhadap masa berakhirnya satu hukum dan berlakunya hukum baru. Dua hukum tersebut (baik yang lama maupun baru) diketahui oleh Allah, hanya saja manusia tidak mengetahuinya karena keterbatasan kemampuan yang dimiliki. Karena itu, Ibn Hazm (384-456 H) mengatakan bahwa naskh adalah salah satu metode penafsiran dengan cara menangguhkan (mengakhirkan) penjelasan. Penangguhan penjelasan (ta'khîr al-bayân) itu ada yang terkait dengan kata/kalimat dan ada yang terkait dengan perbuatan.

${ }^{54}$ Alquran adalah satu kesatuan yang tidak mungkin terjadi perbedaan di dalamnya. Perbedaan itu sejatinya hanya dalam perspektif kemanusiaan yang sangat nisbi dan terbatas. Contohnya tentang penciptaan Adam yang disebutkan secara berbeda dalam Q.S. Âli 'Imrân [3]:59, Q.S. al-A'râf [7]:12, Q.S. al-Hijr [15], dan Q.S. al-Anbiyâ' [21]:30.

${ }_{55}$ Qirâ'ât adalah ilmu untuk mengetahui cara baca (pengucapan) lafaz-lafaz Alquran, baik yang disepakati maupun yang diperselisihkan oleh para ahli qira'at. Qira'at dibagi menjadi dua yaitu shahîhah (sahih/sah) dan syâdzdzah (aneh/ jarang). Lihat Ibn Mujâhid, al-Sab'ah fî al-Qirâ'ât (di-tahqî́q oleh Shawqî Dhayf), (Kairo: Dâr al-Kutub, 1999), h. 47-50.

${ }^{56}$ Lihat Fâyed, al-Dakhîl..., Juz 1, 18-34.

57 Para ulama berbeda dalam mendefinisikan sunnah. Namun menurut mayoritas ahli hadis, sunnah didefinisikan sama dengan hadis yakni; perkataan, perbuatan, ketetapan dan karakter Nabi Saw, baik yang bersifat bawaan (khalqiyah) maupun aplikasi keseharian (khuluqiyah). Lihat Muhammad Abu Zahw, al- $\underline{\text { H}}$ adîts wa al-Muhadditsûn, (Kairo: Dâr al-Fikr al'Arabi, 1958), h. 10.

${ }_{58}$ Hadis ini dilansir dari al-'Irbâdh ibn Sâriyah dan statusnya dinilai $\underline{h} a s a n$ shahih oleh al-Tirmidzi. Lihat al-Tirmidzi, Sunan al-Tirmidzî..., Juz 3, h. 267.

59 Hadis ini merupakan penggalan dari isi khutbah Nabi Saw pada waktu haji wada, dan dilansir dari Ibn 'Abbas. Lihat Mâlik ibn Anas, al-Muwaththa' ditahqiq Muhammad Fu'ad 
riwayat lain yang yang diceritakan oleh al-Awza'i (88-157 H) dari Hassan ibn 'Athiyah (w.130 H), ia berkata: "Wahyu diturunkan kepada Nabi Saw dan Jibril kemudian menyiapkan sunah sebagai penafsirnya." Hal senada juga dikatakan Mak-hûl (w.113 H) bahwa Alquran sangat butuh kepada sunah. Bahkan Yahya ibn Abi Kathîr (w.132 H) mengatakan, sunah adalah penjelas dan penafsir Alquran. ${ }^{60}$

Namun demikian, ulama berbeda pendapat mengenai berapa banyak ayat yang dijelaskan atau ditafsirkan Nabi Saw. Namun secara umum dapat dikelompokkan menjadi dua golongan. Pertama, mengatakan bahwa seluruh isi Alquran telah ditafsirkan oleh Nabi Saw. Diantara dalil yang digunakan kelompok ini adalah Q.S. al-Nahl [16]:44. Menurut Ibn Taymiyah (661-728 H), frase li tubayyina li an-nâs pada ayat ini mencakup semua penjelasan, baik secara leksikal (alfâzh) maupun makna-makna (ma'ânî). ${ }^{61}$ Mereka juga melansir salah satu riwayat dari Abu 'Abdurrahman alSulami, dia berkata: "Kami diberitahu orang-orang yang mengajari kami cara baca Alquran seperti Utsmân ibn 'Affan, 'Abdullah ibn Mas'ud dan lainnya bahwa, ketika mereka belajar (Alquran) dari Nabi Saw sepuluh ayat, mereka tidak berpindah ke ayat lain sebelum memahami dan mengamalkan isinya dengan baik." Kemudian mereka berkata: "Maka kami pun mempelajari Alquran, teori dan aplikasinya sekaligus."62

Kelompok kedua berpendapat bahwa Nabi Saw menafsirkan Alquran dalam jumlah sangat sedikit. ${ }^{63}$ Di antara dalil yang dijadikan dasar adalah riwayat dari al-Bazzâr (w.292 H) dari 'Aisyah (w.58 H), dia berkata: "Rasul Saw tidak menafsirkan

'Abdul Bâqî, (Kairo: Musthafa al-Bab al-Halabi, 1985), Juz 2, h. 899; Lihat juga Muhammad Abu Shahbah, A'lâm al-Muhadditsîn, (Kairo: Dâr al-Kitab al-‘Arabi, 1962), h. 12.

${ }^{60}$ Riwayat-riwayat tersebut dapat dilihat misalnya pada Muhammad ibn Ahmad al-Anshari al-Qurthubi (selanjutnya ditulis al-Qurthubi), al-Jâmi' li Ahkâm al-Qur'ân wa al-Mubayyin li Mâ Tadhammana min al-Sunnah wa Ahkâm al-Furqân (selanjutnya ditulis al-Jâmi' li Ahkâm al-Qur'ân), (Kairo: Dâr alKutub al-Mashriyah, 1964), Juz 1, h. 39.

${ }^{61}$ Lihat Ibn Taymiyah, Muqaddimah fî Ushûl al-Tafsîr..., h. 35.

${ }_{62}$ Menurut Ibn Taymiyah, hadis di atas menunjukkan bahwa para sahabat di samping belajar cara baca Al-Qur'an, juga belajar tafsir dan cara mengaplikasikannya dalam kehidupan sehari-hari. Lihat Ibn Taymiyah, Muqaddimah fî Ushûl al-Tafsîr..., h. 36.

${ }^{63}$ Diantara yang mengatakan demikian adalah al-Zarkasyî dan al-Suyûthî. Lihat al-Suyûthî, al-Itqân fî ‘Ulûm al-Qur'ân..., Juz 2, h. 178-179.
Alquran kecuali beberapa ayat yang diajari Jibril." ${ }^{64}$ Dalam hadis lain, Rasul Saw secara khusus juga mendoakan Ibn 'Abbâs seraya berkata: "Ya Allah, berilah dia (Ibn 'Abbas) pemahaman tentang agama dan ajarilah takwil/tafsir (Alquran)." ${ }^{5}$ Seandainya Rasul Saw menjelaskan seluruh isi Alquran, maka do'a dalam hadis ini tidak ada fungsinya, sebab semua sahabat, termasuk Ibn 'Abbas, akan dapat menafsirkan Alquran melalui penjelasan dan penafsiran baginda Muhammad Saw. ${ }^{66}$ Dengan demikian, dapat ditarik kesimpulan bahwa Nabi tidak menafsirkan seluruh isi Alquran, tapi beliau hanya menafsirkannya dalam jumlah yang sangat sedikit.

Perbedaan dua kelompok di atas kemudian dimoderasi oleh kelompok ketiga yang diwakili antara lain oleh Husain al-Dzahabi dan Fayed. ${ }^{67}$ Mereka mengatakan bahwa Rasul Saw menjelaskan/menafsirakan Alquran kepada sahabatnya dalam jumlah yang cukup banyak sebagaimana dapat dijumpai dalam kitab-kitab hadis sahîh. Namun beliau tentu saja tidak menafsirkan seluruh isi Alquran, sebab di dalamnya ada ayat-ayat yang hanya dapat diketahui oleh Allah Swt, ada ayat-ayat yang dapat diketahui para ulama, ada ayat-ayat yang diketahui oleh orang Arab dari bahasanya dan ada juga ayatayat yang dapat dipahami oleh semua orang. ${ }^{68}$

Adapun metode penafsiran Alquran dengan sunah, adalah: (1) bayân al-mujmal69 (menjelaskan

64 Mengomentari riwayat di atas, Qâdhî 'Abd alibn 'Athiyah mengatakan bahwa ayat-ayat yang ditafsirkan Rasul melalui pengajaran Jibril adalah yang terkait dengan hal-hal supranatural, seperti hari kiamat, surga neraka dan semacamnya yang tidak mungkin diketahui hakekatnya kecuali

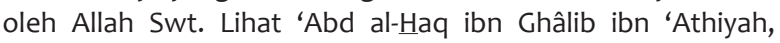
Muqaddimatân fî 'Ulûm al-Qur'ân, (Kairo: Maktabah al-Khanji, 1972), h. 263.

65 Hadis ini diriwayatkan secara beragam oleh beberapa ahli hadis. Dalam Shahîh al-Bukhârî, misalnya, tidak ada redaksi; wa 'allimhu al-ta'wîl (dan ajarilah ia tentang takwil). Redaksi ini hanya terdapat pada Musnad Imam Ahmad, Shahih Ibn Hibbân

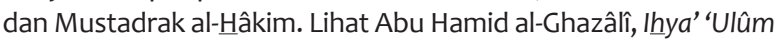
al-Dîn, (Kairo: Musthafa al-Bab al-Halibî, t.th.), Juz 1, h. 379.

${ }^{66}$ Fâyed, al-Dakhîl fi Tafsîr al-Qur'ân al-Karîm..., Juz 1, h. 41.

${ }^{67}$ Lihat Fâyed, al-Dakhîl fi Tafsîr al-Qur'ân al-Karîm..., Juz 1, h. 43-44.

68 Empat pembagian ayat Al-Qur'an sebagaimana dijelaskan al-Dzahabî di atas merujuk kepada riwayat yang dilansir Ibn Jarir dari Ibn 'Abbas. Lihat al-Dzahabî, al-Tafsîr wa al-Mufassirûn..., Juz 1, h. 53.

${ }^{69}$ Contohnya adalah penjelasan Rasul tentang tata cara shalat, zakat dan haji melalui hadisnya: "Shalatlah kalian seperti halnya kalian melihat aku shalat," dan "Ambillah dariku tata cara ibadah haji kalian.” (HR. al-Bukhari). Lihat al-Bukhari, Shahîh al- 
ayat yang global), (2) taqyîd al-muthlaq70 (membatasi yang mutlak), (3) takhshîsh al-'âm ${ }^{71}$ (mengkhususkan yang umum), 4) taudhih almusykil72 (menjelaskan yang ambigu), (5) bayân al-naskh ${ }^{73}$ (penjelasan dengan cara menghapus/ mengganti), (6) bayân al-ta'kîd ${ }^{74}$ (penjelasan untuk menegaskan dan menguatkan), (7) taqrîr mâ sakata 'anhu al-qur'ân'5 (menetapkan hukum yang belum disebutkan dalam Alquran). ${ }^{76}$ Melalui metode-metode inilah sunah dapat menjelaskan isi Alquran.

\section{Pendapat Sahabat dan Tabiin}

Sepeninggal Rasul Saw, sahabat menjadi rujukan dalam penafsiran Alquran. Demikian sebab mereka adalah generasi yang paling tahu mengenai hal ikhwal Alquran; mulai dari proses penurunan hingga pemahaman dan aplikasi

Bukhârî..., Juz 5, h. 69.

70 Contohnya adalah pembatasan Rasul Saw terhadap kemutlakan hukum potong tangan bagi pencuri sebagaimana tertera dalam Q.S. al-Mâ'idah [5]:38, dibatasi sampai pergelangan tangan. Hadis ini dapat dilihat pada misalnya, Sunan Abu Dawud, Sunan al-Nasa'i, Sunan Ibn Majah dan Musnad Ahmad.

${ }^{71}$ Contohnya adalah pen-takhshish-an Rasul terhadap keumuman frase al-zhulm (kezhaliman) yang tertera dalam Q.S. al-An'âm [6]:83 dengan al-syirk (menyekutukan Tuhan), seraya bersabda: "Sesungguhnya yang dimaksud al-zhulm (pada ayat ini) adalah al-syirk (menyekutukan Tuhan). Lihat alSuyûthî, al-Itqân fî ‘Ulûm al-Qur'ân..., Juz 2, h. 193.

${ }^{72}$ Contohnya adalah penjelasan Rasul terhadap al-khayth al-abyadh dan al-khayth al-aswad dalam Q.S. al-Baqarah [2]:178 yang dipahami secara ambigu oleh sebagain sahabat dengan memaknainya sebagai tali putih dan hitam. Maka Rasul mengatakan: "la adalah putih (terang)-nya siang dan hitam (kelam)-nya malam.” (HR. al-Bukhari). Lihat Muhammad ibn Isma'il al-Bukhari, Shahîh al-Bukhârî, (Bayrut: Dâr ibn Katsir, 2002), Juz 6, h. 31.

73 Bagi kelompok yang menyetujui adanya naskh (penghapusan) Alqura dengan sunah maka mereka memberikan contoh antara lain, ayat yang membolehkan wasiat bagi orangtua dan kerabat ahli waris sebagaimana dalam Q.S. alBaqarah [2]: 180 dinaskh dengan hadis; "Tidak ada wasiat bagi ahli waris”. Lihat al-Tirmidzi, Sunan al-Tirmizhî..., Juz 2, h. 193.

${ }^{74}$ Misalnya adalah hadis Nabi Saw yang sejalan dengan AlQuran seperti hadis; "Tidak halal harta seseorang kecuali yang diperoleh dengan cara yang baik" (HR. al-Dayla‘̂̂). Hadis ini menguatkan firman Allah dalam Q.S. al-Nisâ' [4]:29 yang melarang memakan harta dengan cara yang batil. Lihat Fâyed, al-Dakhîl fi Tafsîr al-Qur'ân al-Karîm..., Juz 1, h. 46.

75 Beberapa hal yang belum dijelaskan status hukumnya oleh Al-Qur'an kemudian dijelaskan oleh Rasul melalui sunnahnya. Contohnya adalah keharaman memakan binatang buas yang bertaring, burung yang berkuku tajam dan keledai rumahan serta keharaman menikahi bibi/tante, baik dari jalur ibu maupun ayah. Lihat Sayyid Sabiq, Fiqh al-Sunnah, (Kairo: Dâr al-Manâr, 1998), Juz 3, h. 59.

${ }^{76}$ Fâyed, al-Dakhîl fi Tafsîr al-Qur'ân al-Karîm..., Juz 1, h. 44. ajaran Alquran dalam keseharian.77 Dalam dunia penafsiran, sahabat merujuk kepada Alquran, sunah, dan jika tidak didapatkan keterangan dari keduanya, mereka berijtihad sendiri dan sangat sedikit yang merujuk kepada data-data isra'iliyat. ${ }^{78}$

Pada era kepemimpinan Abu Bakar dan 'Umar ibn Khattab, perbedaan penafsiran di kalangan sahabat masih sangat minim, ${ }^{79}$ tatapi pada era 'Utsmân ibn 'Affan, seiring terjadinya perebutan kekuasaan antar klan Arab dan penyebaran Islam ke segenap penjuru dunia, perbedaan pada bidang tafsir Alquran pun mulai tumbuh. Kendati harus diakui bahwa perbedaan (ikhtilâf) di zaman itu masih bersifat tanawwu' (variatif) belum sampai kepada tadhâd (kontradiktif).

Karena itu, tidak berlebihan bila al-Suyuthi (849-911 H), hanya mencatat sekitar sepuluh penafsir saja dari kalangan sahabat, yaitu: Abu Bakar al-Shiddiq (w. 13 H/634 M); 'Umar ibn al-Khattab (w.23 H/644 M); Utsmân ibn 'Affan (w.35 H/656 M); 'Ali ibn Abi Thalib (w. 40 H/661 M); Ibn Mas'ud (w.32 H/653 M); Zayd ibn Tsabit (w.45 H/665 M); Ubay ibn Ka'b (w.20 H/640 M); Abu Musa al- Asy'ari (w. 44 H/664 M); 'Abdullah ibn Zubayr (w. 73 H/692 M ); dan 'Abdullah ibn 'Abbas (w.68 H/687 M). ${ }^{80}$

Walaupun demikian, tidak semua sahabat memiliki kesempatan dan kemampuan yang sama dalam dunia penafsiran Alquran. Mereka sangat beragam kemampuannya; ada yang memiliki pemahaman yang sangat mendalam, ada juga yang tidak; ada yang memiliki kesempatan cukup luas untuk mengakses informasi dari Rasul Saw,

77 Ibn Taymiyah, Muqaddimah fî Ushûl al-Tafsîr..., h. 95; Lihat pula Ibn Katsir, Tafsîr al-Qur'ân al-'Azhîm..., Juz 1, h. 13

${ }^{78}$ Mengenai hal ini dapat dilihat misalnya dalam hadis riwayat al-Tirmidzi yang berisi tentang dialog Nabi Saw dengan Mu'adz ibn Jabal sebelum ia diutus ke Yaman sebagai hakim. Lihat al-Tirmidzi, Sunan al-Tirmidzî..., Juz 3, h. 137.

${ }^{79}$ Ada beberapa hal yang menjadikan dua era khilafah rashidah (Abu Bakar dan Umar) ini masih sangat minim perbedaan dalam penafsiran, antara lain: 1) dua era tersebut masih dekat masanya dengan masa Rasul Saw; 2) pada dua era itu para sahabat masih berpegang teguh dengan prinsip musyawarah dalam menyelesaikan permasalahan, sehingga perbedaan dapat diminimalisir; 3) para sahabat di dua era ini masih terkonsenterasi pada satu wilayah yakni Madinah dan sekitarnya, sehingga memudahkan proses pengawasan dan controlling; 4) dua era ini masih relatif aman dan belum terjadi pertempuran berdarah seperti halnya era-era setelahnya. Lihat lebih dalam pada Muhammad 'Ali al-Sâyis, Nasy'ah al-Fiqh alIjtihâdî wa Athwâruh, (Kairo: Majma' al-Buhûts al-Islâmiyah, 1970), h. 74.

${ }^{80}$ al-Suyûthî, al-Itqân fî ‘Ulûm al-Qur’ân..., Juz 2, h. 187. 
ada pula yang tidak; ada yang sibuk berpolitik, bekerja dan ada yang menggeluti dunia akademik; ada yang mampu menghafal seluruh isi Alquran, ada pula yang tidak. ${ }^{81}$

Keragaman kondisi sahabat ini berkonsekuensi logis pada keragaman kemampuan mereka dalam menafsirkan Alquran. Karena itu, tidak heran bila diantara sekian banyak sahabat yang kerap menjadi rujukan dalam bidang tafsir hanya ada tiga orang yaitu: 'Ali ibn Abi Thalib (w.40 H/661 M), 'Abdullah ibn 'Abbas (w.68 H/687 M) dan 'Abdullah ibn Mas'ud (w.32 H/653 M).

Kemudian terkait dengan kualitas riwayat (pendapat) sahabat dalam bidang tafsir, dapat diklasifikasikan menjadi tiga hal.

Pertama, riwayat tentang hal-hal yang tidak dapat diintervensi akal (mâ lâ majâla li al-ra'y fîh), seperti riwayat mengenai asbâb al-nuzûl, nâsikh mansûkh dan muhkâm mutasyâbih. Riwayat sahabat dalam konteks ini dapat dibagi menjadi dua jenis; shahîh dan da'îf sanadnya. Jika sanadnya shahih maka riwayat tersebut dapat digunakan sebagai data penafsiran, sebab ia dihukumi sebagai hadis marfû́ (sampai kepada Nabi Saw). Tapi jika sanadnya lemah, maka tidak dapat dijadikan data penafsiran, kecuali bila didukung oleh salah satu diantara dua hal yaitu; ada riwayat dari sahabat lain yang mendukungnya, dan/atau riwayat tersebut berasal dari sahabat senior yang dikenal kredibilitasnya. ${ }^{82}$

Kedua, riwayat mengenai hal-hal yang dapat diintervensi akal (mâ kâna li al-ra'y fîhi majâl). Kebanyakan yang termasuk dalam kategori kedua ini adalah riwayat tentang persoalan ayat-

${ }^{81}$ Bahkan dalam konteks ini, al-Qurthubi (w.671 H) melansir beberapa riwayat dalam kitab tafsirnya. Salah satunya adalah riwayat dari al-Anbârî (304 H) dari Ibn Mas'ud (w.32 H) bahwa dia berkata: "Sesungguhnya sulit bagi kami untuk menghafal Al-Qur'an, tapi mudah untuk mengamalkannya. Sebaliknya, bagi generasi setelah kami, mereka akan mudah menghafal Al-Qur'an tapi sulit untuk mengamalkannya". Riwayat kedua dilansir dari Ibn 'Umar (w.73 H), dia berkata: "Orang yang mulia di antara kami, generasi sahabat Nabi Saw, tidak menghafal Al-Qur'an kecuali satu atau beberapa surat saja namun kami diberi kemampuan untuk mengamalkannya. Dan generasi akhir dari umat Muhammad nanti akan mudah membaca dan menghafal Al-Qur'an, bahkan anak-anak dan orang yang buta sekalipun, sementara mereka tidak mampu untuk mengamalkannya." Lihat al-Qurthubi, al-Jâmi“ li Ahkâm al-Qur'ân..., Juz 1, h. 40.

${ }^{82}$ Ahmad ibn 'Ali ibn Hajar al-'Asqallânî (selanjutnya ditulis ibn Hajar al-'Asqallânî), Hadyu al-Sârî Muqaddimah Fath al-Bârî bi Sharh al-Bukhârî, (Kairo: Maktabah al-Salafîyah, t.th.), h. 16. ayat fikih (âyât al-ahkâm) dan muamalat. Dalam konteks ini, riwayat yang dapat dijadikan sumber data otentik penafsiran hanya yang disepakati (mujma' 'alaih) saja, sementara riwayat yang mukhtalaf fîh $^{83}$ (terjadi perbedaan) tidak dapat digunakan sebagai sumber data otentik penafsiran Alquran. ${ }^{84}$

Ketiga, riwayat tentang cerita-cerita isra'iliyat. Riwayat isra'iliyat yang dilansir dari sahabat harus dikroscek tingkat kesahihannya. Jika mata rantai sanadnya benar-benar tersambung dan terpercaya, maka boleh jadi riwayat tersebut benar. Jika riwayat itu benar, tentu jumlahnya sangatlah sedikit. Sebab sahabat sangat berhatihati dalam melansir isra'iliyat tersebut. Mayoritas isra'iliyat yang dilansir dari sahabat adalah riwayat yang tidak valid karena tidak bersumber langsung dari sahabat, ia hanya riwayat buatan yang kemudian dinisbatkan oleh perawinya kepada sahabat. Karena itu, tidak berlebihan bila Abu Zahrah (1898-1974 M) misalnya, menilai bahwa mayortias riwayat isra'iliyat yang dilansir dari sahabat berstatus maudhû'ah (palsu). Dikatakan demikian sebab banyak data yang membuktikan kehati-hatian sahabat dalam melansir isra'iliyat, ${ }^{85}$ mereka sudah merasa cukup dengan keterangan yang didapat dari Alquran dan sunah Nabi Saw. ${ }^{86}$

Penafsiran sahabat itu kemudian dikembangkan oleh generasi tabiin. Berbeda dengan para sahabat yang secara umum bermukim di Madinah,

83 Menurut al-Suyuthî, perbedaan riwayat sahabat mengenai tafsiran ayat-ayat hukum ini sedapat mungkin dikompromikan (al-jam'), namun bila tidak memungkinkan maka dapat dilakukan pentarjihan (menetapkan pendapat yang kuat diantara beberapa pendapat yang ada) dengan melihat misalnya sisi kualitas, senioritas dan kredibilitasnya. Lihat alSuyûthî, al-Itqân fî ‘Ulûm al-Qur’ân..., Juz 2, h. 103.

${ }^{84}$ Termasuk dalam konteks ini, Abu Zahrah (1898-1974 M) memasukkan pendapat satu sahabat mengenai hukum halal haram yang tidak mendapatkan dukungan atau sanggahan dari sahabat lain sebagai sumber otentik penafsiran. Lihat Muhammad Ahmad Mushthafa Ahmad Abu Zahrah (selanjutnya ditulis Abu Zahrah), al-Mu'jizah al-Kubrâ: al-Qur'ân, (Kairo: Dâr al-Fikr al-‘Arabi, 1970), h. 591.

${ }^{85}$ Antara lain adalah riwayat dari Ibn 'Abbas yang memperingatkan para sahabat agar tidak kerap melansir riwayat isra'iliyat dari Ahl Kitab seraya berkata: "Wahai kaum muslimin, bagaiaman bisa kalian bertanya kepada Ahli Kitab tentang suatu perkara, sementara kitab kalian yang diturunkan kepada Nabi Saw adalah berita terbaru yang barusan saja kalian baca. Sungguh Allah telah menceritakan kepada kalian bahwa Ahli Kitab telah merubah ketetapan Allah dan mengganti kitab mereka dengan tangan mereka sediri..." Lihat al-Bukhari, Sahih al-Bukhari..., Juz 3, h. 237.

${ }^{86}$ Abu Zahrah, al-Mu'jizah al-Kubrâ..., h. 592. 
terutama pada zaman Abu Bakar dan 'Umar ibn al-Khattab, pada masa generasi sahabat kecil dan tabiin, tokoh-tokoh Islam sudah tersebar luas di berbagai kota. Di setiap kota terkemuka seperti di Madinah, Mekah, Irak terdapat sejumlah mufasir ternama.

Beberapa nama mufasir yang bermukim di Mekah yang umumnya berguru dan belajar kepada 'Abdullah ibn 'Abbas, antara lain, Mujahid ibn Jabr (21-103 H/641-721 M), Sa‘id ibn Jubayr (w.94 H/712 M), 'Ikrimah maula ibn 'Abbas (w.106 H/724 M), dan 'Athâ' ibn Abi Rabah al-Makkî (w.114 H/723 M). ${ }^{87}$ Sementara yang bermukim di Madinah, yang berguru kepada Ubay ibn Ka'b, misalnya, Zayd ibn Aslam (w.136 H), Abu al-'Âliyah (w.90 H) dan Muhammad ibn Ka'ab (w. $118 \mathrm{H}$ ). Dan beberapa ahli tasfir yang bermukim di Kufah, yang kebanyakan merupakan murid dari Ibn Mas'ud, antara lain, al-Nakha'î (w.95 H/713 M), 'Alqamah ibn Qays (w.102 H/720 M), dan al-Sya'bî (w.105 H/723 M).88

Sumber-sumber penafsiran tabiin adalah Alquran, sunah, pendapat sahabat, riwayat Ahli Kitab (isra'iliyat) dan ijtihad. Mengomentari sumber penafsiran ini, Najmuddin al-Thufi (w.716 $\mathrm{H} / 1216 \mathrm{M}$ ) mengatakan bahwa keberagaman sumber penafsiran tabiin disebabkan, antara lain; tabiin mendapatkan sumber tafsir dari sahabat yang mereka temui saja tanpa berusaha untuk melengkapi atau mengkonfrontirnya kepada sahabat lain. Kemudian mereka berijtihad sendiri untuk melengkapi penafsiran itu dengan mengambil data dari bahasa Arab, sunah Nabi, Alquran dan sumber lain yang dianggap cocok seperti sejarah umat terdahulu dan riwayat isra'iliyat, sehingga berkembanglah beragam bentuk penafsiran dan menyebarlah berbagai model tafsir infiltratif (al-dakhîl). ${ }^{89}$

Berdasarkan fakta tersebut, dapat dicatat

${ }^{87}$ Tentang mereka itu, Sufyân al-Tsaurî (97-161 H) berkata: "Silahkan kalian ambil tafsir dari empat orang, yakni Sa"îd ibn Jubayr, Mujahid, 'Ikrimah, dan al-Dhahhâk". Lihat Ibn Taymiyah, Muqaddimah fî Ushûl al-Tafsîr..., h. 61. Lihat juga Tim Penyusun, Mukadimah Al-Qur'an dan Tafsirnya (Jakarta: Departemen Agama Rl, 2008), h. 49.

${ }^{88}$ Ibn Taymiyah, Muqaddimah fî Ushûl al-Tafsîr..., h. 61. Lalu bandingkan dengan Fâyed, al-Dakhîl fî Tafsîr al-Qur'an alKarîm..., Juz 1, h. 68-69.

${ }^{89}$ Sulayman ibn 'Abd al-Qawi ibn al-Karîm al-Thûfî alBaghdâdî -biasa dikenal Najmuddin al-Thûfî-, al-Iksîr fî 'Ilm al-Tafsîr, di-tahqiq 'Abd al-Qâdir Husayn, (Kairo: Maktabah alÂdâb, 1977), h. 36. bahwa setidaknya ada empat karakteristik tafsir tabiin. Pertama, variasi tafsir tabiin jauh lebih banyak bila dibandingkan dengan tafsir sahabat. Kedua, tafsir tabiin sudah mulai banyak terinfiltrasi oleh riwayat palsu dan isra'iliyat. Ketiga, terdapat benih-benih tafsir sektarian, baik dalam bidang hukum (fikih) maupun teologi. Ini merupakan konsekuensi logis dari lahir dan berkembangnya sekte dan tradisi berijtihad kala itu. Keempat, kendati demikian, tafsir tabiin tetap menjaga tradisi periwayatan dan transmisi secara oral sebagaimana yang terjadi pada tafsir sahabat. ${ }^{\circ}$

Berdasarkan data dan fakta di atas, para ulama ${ }^{91}$ berbeda pendapat mengenai boleh tidaknya merujuk kepada tafsir tabiin. Satu pihak menolak penafsiran tabiin karena setidaknya dua alasan; pertama, secara kronologis mereka tidak mendengar langsung dari Nabi Saw atas apa yang mereka tafsirkan. Kedua, tabiin tidak menyaksikan langsung proses penurunan Alquran..$^{92}$

Sementara pihak lain menerima tafsiran tabiin dengan alasan bahwa mayoritas tafsir tabiin berkaitan dan bersumber dari hasil penafsiran sahabat. Pendapat ini merujuk pada perkataan Mujahid ibn Jabr (21-103 H) dan Qatadah ibn Di‘âmah (61-118 H) -sebagaimana dilansir alSuyuthi- yang menyatakan bahwa tidak ada satu ayatpun dari Alquran, kecuali tafsirannya telah didengar dari sahabat. Akan tetapi, apabila penafsiran itu cenderung menggunakan rasio, ia tidak wajib dijadikan sebagai data penafsiran. ${ }^{93}$

Terlepas dari dua pendapat di atas, tafsir tabiin yang disepakati dan yang terkait dengan hal-hal yang tidak dapat diintervensi akal94 tentu

${ }^{90}$ Fâyed, al-Dakhîl fî Tafsîr al-Qur'an al-Karîm..., Juz 1, h. 69-71.

${ }^{91}$ Salah satunya adalah Ahmad ibn Hanbal (164-241 H/780$855 \mathrm{M}$ ), dia mengatakan bahwa pendapat (tafsiran) tabiin itu ada yang boleh dijadikan sumber data penafsiran, ada juga yang tidak diperbolehkan. Lihat al-Suyûthî, al-Itqân.., Juz 2, h. 179.

${ }_{92}^{2}$ Ibnu Taymiyah menyatakan bahwa pernyataan (tafsir) tabiin tidak boleh dijadikan hujjah (data penafsiran) bagi umat sesudahnya. Sementara hasil ijma' mereka atas sesuatu dapat dijadikan hujjah. Akan tetapi apabila terjadi perbedaan pendapat, pendapat yang satu tidak dapat dijadikan hujjah atas lainnya juga tidak dijadikan hujjah oleh umat sesudahnya. Sikap terbaik adalah mengembalikan segala permasalahan AlQuran dan Sunah kepada keumuman bahasa Arab, atau perkataan para sahabat. Lihat Ibn Taymiyah, Muqaddimah fî Ushûl alTafsîr..., h. 105.

${ }^{93}$ Lihat al-Suyûthî, al-Itqân fî ‘Ulûm al-Qur’ân..., Juz 2, h. 179.

${ }_{94}$ Mengenai penafsiran tabi'i yang terkait dengan hal-hal di luar wilayah ijtihad, al-Dzahabî menilai bahwa jika sumbernya berasal dari tabi'i yang terkenal mengambil riwayat dari ahli 
boleh dan bahkan harus dijadikan sumber data penafsiran. Sementara tafsir yang diperselisihkan dan yang terkait wilayah ijtihad tentu saja tidak scara spontan dapat dijadikan data penafsiran. Dalam konteks kedua inilah Abu Hanifah (80-150 H) pernah mengatakan, hum rijâl wa nahnu rijâl95 (mereka [tabiin] adalah generasi [yang dapat berijtihad] dan kami juga generasi [yang mampu berijtihad]).

Dengan demikian dapat disimpulkan bahwa tafsir tabiin tidak dapat dijadikan rujukan, kecuali dengan dua syarat, yakni: pertama, riwayat mereka tidak terkait masalah ijtihadi. Kedua, tabiin yang bersangkutan tidak dikenal sebagai tukang pelansir riwayat dari ahli kitab. Bila kedua syarat ini terpenuhi, maka tafsiran mereka dapat diterima, jika sebaliknya, maka pendapat mereka tidak dapat dijadikan sumber data penafsiran.

\section{Bahasa Arab}

Sumber otentik penafsiran selanjutnya adalah bahasa Arab. Bahasa Arab dijadikan salah satu sumber otentik penafsiran, sebab Alquran diturunkan dengan menggunakan bahasa Arab (Q.S. Yûsuf [12]: 2; Q.S. An-Nahl [16]:103; Q.S. alDukhân [44]: 58; Q.S. as-Syu'arâ' [26]: 192-195). Dengan demikian, merujuk kepada bahasa Arab dalam penafsiran Alquran adalah keniscayaan yang tak terbantahkan.

Yang dimaksud merujuk kepada bahasa Arab adalah merujuk kepada sya'ir, puisi, prosa, surat menyurat dan dialek Arab. Selian itu, penafsir juga harus merujuk kepada kaidah dan rahasiarahasia bahasa Arab. Yang dimaksud kaidah dan rahasia bahasa Arab adalah makna kosa kata, diksi, penjelasan kalimat, gaya bahasa yang meliputi; keindahan (badî'), ketepatan (ma'ânî), kejelasan (bayân) dan semantik (dalâlah) serta berbagai aturan main lainnya yang ditetapkan para ahli gramatikal dan sastra Arab. ${ }^{96}$

kitab, maka penafsirannya tidak dapat dijadikan sumber data. Lihat al-Dzahabî, al-Tafsîr wa al-Mufassirûn..., Juz 2, h. 128-129.

95 Redaksi lengkap statemen Abu Hanifah itu -sebagaimana dikutip Abu Zahrah- adalah "Idzâ Âla al-Amr llâ alHasan wa Ibrâhîm, fa-Hum Rijâl wa Nahnu Rijâl” (jika perkara [pendapat] ini berasal dari Hasan al-Bashri (w.110 H) dan Ibrahim ibn Adham (w.162 H), maka mereka lelaki kami juga lelaki). Maksudnya, mereka dapat berijtihad, kami juga mampu berijtihad. Lihat Abu Zahrah, al-Mu'jizah al-Kubra..., h. 593-594.

${ }^{96}$ Lihat Fâyed, al-Dakhîl fî Tafsîr al-Qur'ân al-Karîm..., Juz 1, h. 74-75.
Urgensi merujuk kepada bahasa Arab dalam penafsiran Alquran dipertegas oleh Nabi Saw melalui salah satu sabdanya: "A'ribû al-Qur'ân wa-l-tamisû gharâ'ibah" (tafsirilah Alquran dengan merujuk kepada kaidah dan aturan main bahasa Arab dan carilah penjelasan tentang kata-kata yang gharîb (aneh/asing/sukar)). ${ }^{97}$ Mengomentari riwayat ini, Ibn 'Athiyah (481-541 H) mengatakan, meng-i'rab Alquran (menafsirkannya dengan kaidah dan aturan main bahasa Arab) adalah asal usul syariat Islam, sebab hanya melalui itu maknamakna lafazh Alquran-yang darinya syariat dibangun-dapat dipahami dan dimengerti..$^{98}$

Ibn 'Abbas (w. $68 \mathrm{H}$ ) juga kerap merujuk kepada bahasa Arab, khususnya sya'ir dan prosa-prosanya. Dalam konteks ini, dia pernah mengatakan; "Jika kalian bertanya kepadaku tentang makna kata-kata yang gharîb (asing/ aneh/sukar) dalam Alquran, maka carilah di dalam syai'r, sebab sya'ir adalah dîwân (perpustakaan)nya orang Arab." 99 Statemen Ibn “Abbas ini menegaskan betapa sya'ir (bahasa Arab) adalah sumber primer tafsir Alquran.

Saking pentingnya bahasa Arab sebagai salah satu sumber penafsiran, Mujahid ibn Jabr (21-104 H) sampai melarang orang yang beriman kepada hari akhir menafsirkan Alquran tanpa menguasai bahasa Arab. ${ }^{100}$ Bahkan Imam Malik ibn Anas (93$179 \mathrm{H}$ ) juga pernah berjanji untuk menghukum siapapun yang berani menafsirkan Alquran tanpa

${ }^{97}$ Diriwayatkan Ibn Abi Syaibah, Abu Ya'la al-Mawshilî dan al-Baihaqî dari Abu Hurairah. Dikatakan bahwa hadis ini lemah. Lihat Abu al-Fadhl Zaynuddin 'Abdurrahman ibn al-Husayn al'Irâqî (selanjutnya ditulis al-Hafizh al-'Irâqî), al-Mughnî 'an Haml al-Asfâr fî al-Asfâr fi Takhrîj Mâ fî al-Ihyâ' min al-Akhbâr, (Bayrût: Dâr Ibn Hazm, 2005), Juz 1, h. 378.

98 'Abd al-Wahhab Fâyed, Manhaj Ibn 'Athiyah fî Tafsîr alQur'ân al-Karîm, (Kairo: Majma' al-Buhûts al-Islâmiyah, 1973), h. 148.

99 Salah satu bukti kepiawaian Ibn 'Abbas dalam menafsirkan Al-Qur'an dengan rujukan sya'ir-sya'ir Arab adalah peristiwa musâ'alah (pertanyaan) Nâfi' ibn al-Azraq (w. 65 H) kepada Ibn 'Abbas tentang berbagai persoalan. Cerita ini dapat dilihat pada al-Suyûthî, al-Itqân fi. 'Ulûm al-Qur'ân..., Juz 1, h. 119. Lihat juga Muhammad Ahmad al-Dâlî, Masâ'il Nâfi ibn al-Azraq 'an 'Abdillah ibn 'Abbâs, (Damaskus: al-Jaffân wa al-Jâbî li alThibâ‘ah wa al-Nasyr, 1993).

${ }^{100}$ Mujahid berkata: "Orang yang beriman kepada hari akhir, tidak boleh berbicara (tentang tafsiran) Kitab Allah (AlQur'an) jika ia tidak pandai bahasa Arab". Sementara Imam Malik berkata: "Sungguh jika didatangkan kepadaku seorang penafsir Kitabullah yang tidak mengerti bahasa Arab, niscaya aku akan menghukumnya.” Lihat al-Zarkasyî, al-Burhân fî ‘Ulûm al-Qur'ân..., Juz 1, h. 292. 
merujuk dan menguasai bahasa Arab. ${ }^{101}$

Dari penjelasan di atas terlihat betapa Nabi, sahabat, tabiin dan generasi setelahnya tidak dapat mengabaikan bahasa Arab dalam menafsirkan Alquran. Tak berlebihan bila alSuyuthi mengatakan, penguasaan bahasa Arab bagi yang ingin menafsiri Alquran adalah salah satu kebutuhan primer (dharûrîyah). ${ }^{102}$ Dengan demikian, jelaslah posisi dan urgensi bahasa Arab_-dengan segala macam karakteristik, kaidah dan aturan mainnya- sebagai salah satu sumber primer dan otentik penafsiran Alquran.

\section{5. ljtihad (Akal)}

Sebagaimana dijelaskan sebelumnya bahwa Nabi Saw tidak menafsirkan semua isi Alquran. Dan riwayat yang sahih mengenai penafsiran Alquran juga jumlahnya sangat sedikit. Karena itu, penggunaan akal/rasio dalam dunia penafsiran (tafsîr bi al-ra'y) adalah keniscayaan yang tak terelakkan. Bahkan, sejak masa-masa awal Islam pun tradisi seperti ini sudah mulai tumbuh. Hanya saja harus diakui bahwa tradisi penafsiran bi alra'y di era-era awal Islam masih berkutat seputar tafsir bi al-Ma'tsûr; mulai dari penegasan (ta'kîd), penguatan (tarjîh ), pelemahan (tadh'îf) terhadap suatu riwayat, hingga penjelasan (syarh ), istinbâth dan istisyhâd dengan sya'ir. ${ }^{103}$

Kemudian tradisi penggunaan al-ra'y (rasio) dalam dunia penafsiran ini terus berkembang di masa-masa berikutnya, sehingga sampai pada titik dimana tafsir bi al-ra'y tidak lagi berkelindan dengan tafsir bi al-ma'tsûr, tapi sudah mulai masuk kepada penggunaan rasio secara liar dan subjektif. Penafsiran seperti ini terjadi sangat kentara terutama sejak munculnya berbagai sekte seperti Syi‘ah, Khawarij, Muktazilah, Qadariyah, Jabariyah, Murji'ah dan semacanya. Dengan mengatasnamakan Islam, tiap-tiap sekte kemudian menafsirkan Alquran secara rasional untuk menjustifikasi teologi dan ajaran sekte masing-masing.

Tak pelak, kondisi tersebut menimbulkan beragam reaksi dari para pengkaji tafsir, khususnya

${ }^{101}$ Lihat al-Zarkasyî, al-Burhân fî 'Ulûm al-Qur'ân..., Juz 1, h. 292.

${ }^{102}$ Lihat al-Suyûthî, al-Itqân fî ‘Ulûm al-Qur'ân..., Juz 1, h. 114.

${ }^{103}$ Lihat Fâyed, al-Dakhîl fî Tafsîr al-Qur'ân al-Karîm..., Juz 1, h. 80 . mengenai hukum penafsiran Alquran bi al-ra'y. Menanggapi hal ini, para ulama secara umum dapat dikelompokkan menjadi dua. Sebagian menerima dan menyetujui panafsiran bi al-ra'y/ bi al-ijtihâd, ${ }^{104}$ sementara yang lain melarang dan bahkan mengharamkannya. ${ }^{105}$

104 Diantara argumentasi yang digunakan kelompok ini adalah: (1) Terdapat beragam ayat yang menegaskan pentingnya bertadabbur dan bertadzakkur seperti Q.S. al-Baqarah [2]:221, Q.S. al-Dukhân [44]: 58, Q.S. Shâd [38]:29, Q.S. Muhammad [47]:24. Bertadabbur dan bertafakkur tentu tidak dapat dilakukan secara maksimal tanpa pemahaman yang baik terhadap Alquran. Dan pemahaman terhadap isi Alquran membutuhkan penalaran dan ijtihad yang berkesinambungan; (2) Ditemukan data-data penafsiran yang beragam dari generasi sahabat dan tabiin. Keberagaman penafsiran itu di satu sisi menunjukkan bahwa Rasul Saw tidak menafsirkan seluruh isi Alquran, dan di sisi lain disebabkan karena para sahabat dan tabiin menggunakan ijtihad masing-masing dalam menafsirkan Alquran. (3) Ibn 'Abbas dido'akan langsung oleh Rasul Saw; Allahumma Faqqih-hu fi al-Dîn wa 'Allim-hu al-Ta'wîl. Makna takwil di sini tentu tidak terbatas pada pentakwilan yang diajarkan Rasul saja, tapi bersifat umum, termasuk pentakwilan yang dilakukan Ibn 'Abbas. Jika yang dimaksud takwil pada hadis ini terbatas pada pentakwilan Rasul semata, maka do'a beliau kepada Ibn 'Abbas tidak ada manfaatnya. Dengan demikian, takwil tersebut bersifat umum dan tentu saja berdasarkan rasio/akal yang baik dan sehat. (4) Ada beberapa riwayat yang menegaskan pentingnya berijtihad, antara lain; diriwayatkan dari 'Ali ibn Abi Thalib bahwa dia ditanya: "Apakah engkau pernah diberi pesan khusus oleh Rasul Saw?" "Ali menjawab: "Kami tidak diberi pesan khusus kecuali apa yang tertuang dalam shahîfah (Alquran) ini. Atau pemahaman yang diberikan Allah kepada seseorang mengenai isi Kitab-Nya." Ketika Ibn Mas‘ud ditanya mengenai hukum waris bagi wanita yang dinikahi, lalu suaminya mati sebelum sempat memberi mahar dan berbulan madu, Ibn Mas'ud pun berkata: "Menurut pendapatku, dia harus mendapat mahar mitsil, maka tidak boleh ada dendam dan permusuhan. Seandainya pendapatku ini benar, maka itu dari Allah, jika salah maka itu dari saya dan setan, Allah dan Rasul-Nya bebas dari kesalahan pendapat ini." Lihat Fâyed, al-Dakhîl fî Tafsîr al-Qur'ân al-Karîm..., Juz 1, h. 83-85. Lihat pula Muhammad 'Ali al-Sâyis, Nasy'ah al-Fiqh al-ljtihâdî wa Athwâruh..., h. 40; dan Shihabuddin al-Alûsî, Rûh al-Ma'ânî..., Juz 1, h. 6.

${ }^{105}$ Diantara argumentasi kelompok ini adalah: (1) Firman Allah dalam Q.S. al-Naml [27]:44 "Wa Anzalnâ llayka al-Dzikra li Tubayyina li al-Nâs Mâ Nuzzila llayhim". Pada ayat ini Allah menyandarkan kata al-bayân (penjelasan) Alquran hanya kepada Rasul Saw. Dengan demikian, tidak diperkenankan bagi selain Rasul Saw untuk menjelaskan/menafsirkan Alquran. (2) Ada dua hadis yang mengatakan penafsiran Alquran dengan rasio itu berbahaya dan berpotensi salah. Pertama, "wa man qâla fi al-Qur'ân bi ra'yih fal-yatabawwa' maq'adahu min alnâr" (barangsiapa berkata tentang Al-Qur'an dengan akal/ pendapatnya, maka sejatinya dia sedang menyiapkan tempat duduk dari api neraka). Kedua, "man qâla fi al-Qur'ân bi ra'yih fa ashâba fa qad akhtha'a" (barangsiapan berkata tentang Alquran dengan akalnya, kemudian hasilnya benar, maka sejatinya itu salah). (3) Ada beberapa riwayat dari sahabat dan tabiin yang menunjukkan larangan menafsirkan Alquran dengan rasio. Antara lain adalah riwayat dari Abu Bakar, dia pernah berkata: "Bumi mana yang dapat dijadikan pijakan, langit mana yang mau memberi naungan, bila aku berkata tentang Alquran mengenai sesuatu yang tidak aku ketahui." Riwayat 
Dua pendapat ini sejatinya dapat dikompromikan pada satu titik, yakni; keduanya sama-sama membolehkan penafsiran bi al-ra'y bila penafsirannya sesuai dengan ajaran agama dan bahasa Arab, dan keduanya akan melarang jenis tafsir ini bila hasil penafsirannya berlawanan dengan agama dan bahasa Arab.

Dengan demikian, dapat ditarik benang merah bahwa tafsir bi al-ra'y itu dapat diklasifikasi menjadi dua macam; pertama tafsir yang sesuai dengan dalil syar'i dan kaidah bahasa Arab. Tafsir semacam ini tentu dapat diterima dan dianjurkan untuk dikembangkan. Kedua tafsir yang tidak sesuai dengan dalil syar'i dan kaidah bahasa Arab. Yang semacam ini tentu tidak dianjurkan dan tertolak. Dalam konteks ini, ilmu-ilmu terkait Alquran, baik yang intrinsik maupun ekstrinsik, menjadi prasyarat yang harus dimiliki bagi penafsir bi al-ra'y. Tanpa penguasaan terhadap ilmu-ilmu tersebut, tentu hasil penafsirannya akan sulit diterima, alih-alih dijadikan dasar atau sumber rujukan bagi orang lain.

\section{Penutup}

Dari uraian di atas, dapat disimpulkan bahwa sumber otentik tafsir Alquran-yang merupakan parameter kritik ad-dakhîl—adalah Alquran, sunah, pendapat sahabat dan tabiin yang valid, bahasa arab, dan hasil ijtihad yang berdasarkan datadata objektif dan dapat dipertanggungjawabkan. Penafsiran-penafsiran yang tidak bersumber dari keempat hal tersebut dapat dikategorikan addakhîl (infiltratif), sehingga ia layak untuk dikritisi, direview dan direvisi.

Kritisisme terhadap ad-dakhîl penting dilakukan agar kitab-kitab tafsir-yang merupakan karya turunan dari Alquran-dapat dipastikan steril dan bersih dari segala bentuk penyelewengan data dan informasi. Pada akhirnya, pesan-pesan agung dan

lain mengenai kehati-hatian Sa'id ibn al-Musayyab, dilansir dari Yazid ibn Abu Yazid, "Kami bertanya kepada Sa'id ibn alMusayyab tentang masalah hukum halal dan haram, dia adalah orang yang paling pandai, tapi ketika kami bertanya tentang tafsir Alquran, dia diam dan tak menghiraukan pertanyaan kami." (4) kelompok ini mengatakan bahwa tafsir dengan rasio/ijtihad itu termasuk perkataan berdasarkan asumsi (zhann), dan pernyataan berdasarkan zhann sama dengan menyatakan sesuatu tentang Allah tanpa landasan ilmu, dan berkata mengenai Allah tanpa landasan ilmu hukumnya haram. Lihat Fâyed, al-Dakhîl fî Tafsîr al-Qur'ân al-Karîm..., Juz 1, h. 8183; al-Tirmidzi, Sunan al-Tirmidzî..., Juz 2, h. 157. nilai-nilai luhur Alquran diharapkan dapat dipahami, dibumikan dan diimplementasikan dengan baik oleh umat, sehingga tercapai kemaslahatan hidup di dunia dan akhirat.

\section{Pustaka Acuan}

Abou el-Fadl, Khaled, Speaking in God's Name: Islamic Law, Authority and Women, England: Oneworld, 2003.

Abu Shahbah, Muhammad, A'lâm al-Muhadditsîn, Kairo: Dâr al-Kitab al-'Arabi, 1962.

Abu Zahrah, al-Mu'jizah al-Kubrâ: al-Qur'ân, Kairo: Dâr al-Fikr al-'Arabi, 1970.

Abu Zahw, Muhammad, al-Hadîts wa al-Muhadditsûn, Kairo: Dâr al-Fikr al-'Arabi, 1958.

Alûsî, Syihabuddin, al-, Rûh al-Ma'ânî fî Tafsîr alQur'ân al-'Azhîm wa al-Sab' al-Matsânî, Kairo: Dar al-Manar, 2000.

Antonio, Muhammad Syafii. Muhammad Saw: The Super Manager, The Super Leader, Jakarta: Tazkia Publishing, 2007.

Ashfihânî, al-Râghib, al-, al-Mufradât fî Gharîb alQur'ân, Libanon: Dâr al-Ma'rifah, t.th.

Asqallânî, Ibn Hajar, al-, Hadyu al-Sârî Muqaddimah Fath al-Bârî bi Sharh al-Bukhârî, Kairo: Maktabah al-Salafîyah, t.th.

Bukhari, Muhammad ibn Isma'il, al-, Shahîh alBukhârî, Bayrut: Dâr ibn Katsir, 2002.

Dâlî, Muhammad Ahmad, al-, Masâ'il Nâfi‘ ibn alAzraq 'an 'Abdillah ibn 'Abbâs, Damaskus: alJaffân wa al-Jâbî li al-Thibâ‘ah wa al-Nasyr, 1993.

Dzahabi, Muhammad Husain, al-, al-Ittijâhât al-Munharifah fî Tafsîr al-Qur'ân al-Karâm: Dawâfi'uhâ wa Daf'uhâ, Kairo: Maktabah Wahbah, 2000.

, al-Tafsîr wa al-Mufassirûn, Kairo: Dâr alKutub wa al-Hadîts, 1976.

Echols, John M. dan Hassan Shadily. Kamus Inggris Indonesia, Jakarta: PT. Gramedia, 1975.

Fâyed, 'Abd al-Wahhab, Manhaj Ibn 'Athiyah fî Tafsîr al-Qur'ân al-Karîm, Kairo: Majma' al-Buhûts al-Islâmiyah, 1973.

, al-Dakhîl fî Tafsîr al-Qur'ân al-Karîm, Kairo: Matba'ah al-Hadharah al-'Arabiyah, 1978.

Fayrûz Âbâdî, Majd al-Dîn Muhammad ibn Ya'qûb ibn Muhammad ibn Ibrahim ibn 'Umar alShayrâzî, al-, al-Qâmûs al-Muhîth wa al-Qâbûs al-Wasîth al-Jîmi' li Mâ Dzahaba min Kalâm al-'Arab Shamâmîth, Bayrut: Mu'assasah alRisalah, $1407 \mathrm{H}$. 
Fayyûmî, Ahmad ibn Muhammad ibn 'Ali, al-, alMishbâh al-Munîr fî Gharîb al-Sharh al-Kabîr Kairo: al-Maktabah al-'Ilmiyah, 2000.

Ghazâlî, Abu Hamid, al-, Ihya' 'Ulûm al-Dîn, Kairo: Musthafa al-Bab al-Halibî, t.th.

Gusmian, Islah, Khazanah Tafsir Indonesia dari Hermeneutika Hingga Idiologi, Jakarta: Teraju, 2003.

Hanafi, Hasan, Islam in the Modern World: Religion, Ideology and Development, Kairo: AngloEgyptian Bookshop, 1995.

Husayn, Muhammad al-Khadhir. al-Qadyânîyah, Kairo: al-Makatabah al-Salafîyah, 1932.

Ibn 'Athiyah, 'Abd al-Haq ibn Ghâlib, al-Muharrar alWajîz fî Tafsîr al-Kitâb al-'Azîz, Rabat: Maktabah al-Îmân, 1998. , Muqaddimatân fî 'Ulûm al-Qur'ân, Kairo: Maktabah al-Khanji, 1972.

Ibn al-Atsîr, al-Nihâyah fî Gharîb al-Hadîts wa alAtsar, Bayrut: al-Maktabah al-'Ilmiyah, 1979.

Ibn Katsir. Tafsir al-Qur'ân al-'Azhîm, Kairo: Dâr al-Turâts, 2000.

Ibn Manzhûr, Abu al-Fadhl Muhammad ibn Makram. Lisân al-'Arab, ditahqiq oleh 'Abdullah 'Ali alKabîr, dkk., Kairo: Dâr al-Ma'ârif, t.th.

Ibn Mujâhid. al-Sab'ah fî al-Qirâ'ât, di-tahqîiq oleh Shawqî Dhayf, Kairo: Dâr al-Kutub, 1999.

Ibn Qutaybah. Ta'wîl Musykil al-Qur'ân, di-tahqiq Ahmad Shaqr, Kairo: Maktabah al-Turats, t.th. Imam Ahmad, Musnad Ahmad, Bayrut: Dar Shâdir, t.th.

Irâqî, Abu al-Fadhl Zaynuddin 'Abdurrahman ibn

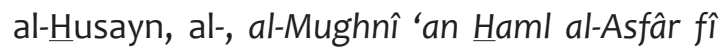
al-Asfâr fi Takhrî̀ Mâ fî al-lhyâ' min al-Akhbâr, Bayrût: Dâr lbn Hazm, 2005.

Ismâ'îl, M. Bakr, Dirâsât fî ‘Ulûm al-Qur'ân, Kairo: Dâr al-Manâr, 1991.

Jalâl, Muhammad Su'âd, al-Bayân wa al-Naskh fî Ushûl al-Figh, Kairo: Maktabah al-Nahdhah, t.th.

Jauzi, Ibn al-Qayyim, al-, Talbîs Iblîs, Iskandariyah: Dâr ibn Khaldun, t.th.

Khalifah, Ibrahim, al-Dakhîl fî al-Tafsîr , Kairo: Universitas Al-Azhar, 1996.

Khuli, Amin, al-, al-Tafsîr: Ma'âlim Hayâtih, Manhajuhu al-Yawm, Kairo: Dâr al-Ma'rifah, 1962.

Mahmud, Basyiruddin, al-Tafsîr al-Shaghîr, edisi Indonesia, Alquran dengan Terjemahan dan Tafsir Singkat, dengan Restu Hadrat Mirza Tahir Ahmad, Khalifatul Masih IV, Edisi II, Jakarta: Dewan Naskah Jemaat Ahmadiyah
Indonesia, 1987.

Musthafa, Ibrahim. et.all., al-Mu'jam al-Wasith, Istanbul: Dâr al-Da'wah, 1990.

Najjâr, Jamâl Mushthafâ 'Abd al-Hamîd 'Abd alWahhâb, al-, Ushûl al-Dakhîl fî Tafsîr Âyi alTanzîl, Kairo: Universitas Al-Azhar, 2009.

Qaththân, Mannâ‘ Khalîl, al-, Mabâhits fî 'Ulûm al-Qur'ân, Bayrût: Mu'assasah al-Risâlah, 1983.

Qurthubi, Muhammad ibn Ahmad al-Anshari, al-, al-Jâmi' li Ahkâm al-Qur'ân wa al-Mubayyin li Mâ Tadhammana min al-Sunnah wa Ahkâm alFurqân, Kairo: Dâr al-Kutub al-Mashriyah, 1964.

Sabiq, Sayyid. Fiqh al-Sunnah, Kairo: Dâr al-Manâr, 1998.

Saenong, Ilham B. Hermeneutika Pembebasan: Metodologi Tafsir Alquran Menurut Hasan Hanafi, Jakarta: Teraju, 2002.

Sâyis, Muhammad 'Ali, al-, Nasy'ah al-Fiqh al-litihâdî wa Athwâruh, Kairo: Majma' al-Buhûts alIslâmiyah, 1970.

Shâlihh, Shubhi, al-, Mabâhits fî 'Ulûm al-Qur'ân, Bayrût: Dâr al-'Illm li al-Malâyîn, 1977.

Sulayman, Musthafâ Muhammad, al-Nâsikh fî Alquran al-Karîm, Kairo: Maktabah al-Amânah, 1991.

Suyuthî, Jalaluddin, al-, al-Itqân fî 'Ulûm al-Qur'ân, Kairo: Dâr al-Manâr, 1999.

, Tadrîb al-Râwî, Kairo: Dâr al-Manâr, 2000.

Syaukânî, Muhammad ibn 'Ali ibn Muhammad, al-, al-Fawâ'id al-Majmû'ah fî al-Ahâdîts alMaudhû'ah, Bayrut: Dâr Shâdir, t.th.

Thûfî, Najmuddin, al-, al-Iksîr fî 'llm al-Tafsîr, ditahqiq 'Abd al-Qâdir Husayn, Kairo: Maktabah al-Âdâb, 1977.

Tim Penulis, 'Âlam al-Ghayb wa al-Shahâdah, Tehran: Markaz al-Nûn Jam‘îyah al-Ma'ârif wa al-Tsaqâfah, 2012.

Tim Penulis, Kamus Bahasa Indonesia, Jakarta: Pusat Bahasa Departemen Pendidikan Nasional, 2008.

Umar, Husayn Muhammad Ibrahim Muhammad, al-Dakhîl fî Tafsîr al-Qur'ân al-Karîm, Kairo: Universitas Al-Azhar, t.th.

Yuslem, Nawir. Ulumul Qur'an, Bandung: Citapustaka Media Perintis, 2011.

Zamakhsyari, Abu al-Qâsim Mahmud ibn 'Umar ibn Muhammad, al-, al-Kasysyâf 'an Haqâ'iq al-Tanzîl wa 'Uyûn al-Aqâwîl fî Wujûh al-Ta'wîl, Kairo: Dâr al-Kutub, t.th. 